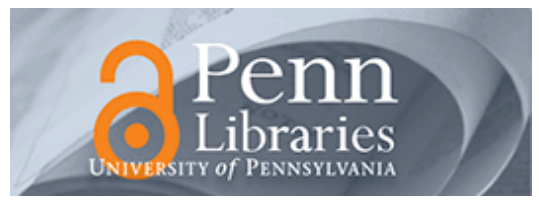

University of Pennsylvania

ScholarlyCommons

Accounting Papers

Wharton Faculty Research

$11-2010$

\title{
Have the Tax Benefits of Debt Been Overestimated?
}

Jennifer L. Blouin

University of Pennsylvania

John E Core

University of Pennsylvania

Wayne R. Guay

University of Pennsylvania

Follow this and additional works at: https://repository.upenn.edu/accounting_papers

Part of the Accounting Commons, and the Taxation Commons

\section{Recommended Citation}

Blouin, J. L., Core, J., \& Guay, W. R. (2010). Have the Tax Benefits of Debt Been Overestimated?. Journal of Financial Economics, 98 (2), 195-213. http://dx.doi.org/10.1016/j.jineco.2010.04.005

This paper is posted at ScholarlyCommons. https://repository.upenn.edu/accounting_papers/100

For more information, please contact repository@pobox.upenn.edu. 


\title{
Have the Tax Benefits of Debt Been Overestimated?
}

\begin{abstract}
We re-examine the claim that many corporations are underleveraged in that they fail to take full advantage of debt tax shields. We show prior results suggesting underleverage stems from biased estimates of tax benefits from interest deductions. We develop improved estimates of marginal tax rates using a nonparametric procedure that produces more accurate estimates of the distribution of future taxable income. We show that additional debt would provide firms with much smaller tax benefits than previously thought, and when expected distress costs and difficult-to-measure non-debt tax shields are also considered, it appears plausible that most firms have tax-efficient capital structures.
\end{abstract}

\section{Keywords}

debt, capital structure, marginal tax rates, taxes

Disciplines

Accounting | Taxation 


\title{
Have the tax benefits of debt been overestimated?
}

\author{
Jennifer Blouin* \\ Email: blouin@wharton.upenn.edu \\ Phone: (215) 898-1266 \\ John E. Core \\ Email: jcore@wharton.upenn.edu \\ Phone: (215) 898-4821 \\ Wayne Guay \\ Email: guay@wharton.upenn.edu \\ Phone: (215) 898-7775 \\ All authors are at the Wharton School, University of Pennsylvania \\ 1300 Steinberg Hall-Dietrich Hall
}

First draft: November 5, 2007

This draft: April 22, 2010

\begin{abstract}
We re-examine the claim that many corporations are underleveraged in that they fail to take full advantage of debt tax shields. We show prior results suggesting underleverage stems from biased estimates of tax benefits from interest deductions. We develop improved estimates of marginal tax rates using a non-parametric procedure that produces more accurate estimates of the distribution of future taxable income. We show that additional debt would provide firms with much smaller tax benefits than previously thought, and when expected distress costs and difficult-to-measure non-debt tax shields are also considered, it appears plausible that most firms have tax-efficient capital structures.
\end{abstract}

JEL Classification: G32; H20

Keywords: Debt; capital structure; marginal tax rates; taxes

* Corresponding author. We appreciate the comments of Gus DeFranco, John Graham, Jarrad Harford, Bob Holthausen, Michael Roberts, Joshua Rauh, Richard Sansing, Doug Shackelford, Terry Shevlin, Andrew Van Buskirk, an anonymous referee, and workshop participants at Dartmouth College, Georgia State University, Harvard Business School, Ohio State University, Penn State University, Southern Methodist University, University of California, Los Angeles, University of Chicago, University of Michigan, the 2008 University of North Carolina Tax Symposium, University of Texas at Dallas, and University of Utah. We also appreciate the research assistance of Amy Gu, Sophia Hamm and Jeffrey $\mathrm{Ng}$, and gratefully acknowledge the financial support of the Wharton School. The marginal tax rates are available from the authors upon request. 


\section{Introduction}

Graham (2000) estimates the amount of interest expense a firm could pay before the expected tax benefits of debt begin to diminish. Graham's analysis suggests that $44 \%$ of firms could double their debt and still receive full tax benefits from interest deductions, a result that has been used to bolster arguments that many firms underutilize debt in their capital structure. In this paper, we show that prior estimates of the tax benefits of debt are overestimated. We develop improved estimates of marginal tax rates (MTRs) using a non-parametric approach to estimating future taxable income that more closely matches the future income stream. Our improved MTRs indicate that additional debt would provide firms with much smaller tax benefits than previously thought, and that when distress costs of adding debt are also considered, the proportion of firms failing to take advantage of the tax benefits of debt appears relatively small.

A corporation's MTR is the present value of current and expected future taxes paid on an additional dollar of income earned today (Shevlin, 1990). The tax code allows carryforwards and carrybacks of taxable income over time; that is, negative taxable income in one period can be used to offset positive taxable income in prior and future periods. As a result, the tax implication of additional income earned today is not simply a function of how much income the firm earns this year, but also how much income the firm earned in prior years and how much it is expected to earn in future years. Because, in our 1980 to 2007 sample period, current period losses can be used to offset taxable income up to 20 years into the future, an estimate of expected future taxes paid on an additional dollar of income requires forecasts of 22-year-ahead taxable income. Further, because taxes owed are not a linear function of taxable income, the distribution of future taxable income (as opposed to simply the expected level of future taxable income) must be estimated to compute the MTR. 
The current state-of-the-art approach to estimating MTRs is developed by Graham (1996a, 1996b), who builds upon the approach in Shevlin (1990). The Graham/Shevlin MTR calculations assume that the level of a firm's future taxable income follows a random walk. While there are strong intuition and theory that stock returns follow a random walk, income is known to mean-revert due to transitory components in accounting income, and economic factors such as entry and exit (e.g., Brooks and Buckmaster, 1976; Brown, 1993). Because of this mean reversion, the random-walk (RW) model predicts future income with error and bias (Barber and Lyon, 1996). Graham (1996a, 1996b, 2000) uses the historical volatility of annual taxable income over the life of the firm as an estimate of the volatility of future taxable income. A concern with this approach is that when a firm's assets and income grow over time, the historical volatility measured since inception is likely to substantially understate the future volatility. As an extreme example, if one were trying to forecast the dollar volatility of future income for Microsoft Corp. as of 2008, the dollar volatility of income that Microsoft experienced in the 1980s would not be of much use given how much larger this firm has become in the last two decades.

Consistent with this intuition, we show that the RW forecasting approach produces inaccurate estimates of mean future income (too high when current income is high and too low when current income is low). Even more problematic, we find that the RW severely underestimates the future volatility of income for all income groups. If the forecast of mean future income is upwardly (downwardly) biased, it is intuitive that estimated MTRs will also be upwardly (downwardly) biased. Further, if forecasted volatility is too low, estimated MTRs for profitable (unprofitable) firms will be upwardly (downwardly) biased. To see the intuition for this result, suppose a firm has recently been, and is currently, unprofitable. For such a firm, an 
extra dollar of income today will have no tax implications unless the firm has positive taxable income in some future year. Therefore, if the volatility of future taxable income is underestimated for this unprofitable firm, the probability that an extra dollar of taxable income today is taxed is also underestimated, and the computed MTR is too low. Analogously, the MTR of a profitable firm will be biased upward when the volatility of future income is too low. It follows that if one examines a group of profitable firms and underestimates their future income volatility, estimates of future taxes owed will be too high, and it will appear that they could obtain substantial tax benefits by increasing their debt levels (i.e., that the firms are underlevered). Consistent with this, our evidence suggests that MTRs calculated using the RW are too high (low) for profitable (unprofitable) firms.

To improve estimates of future income, we develop a "non-parametric" (NP) simulation procedure for forecasting future taxable income. Our approach extends the size and performance matching concepts in Barber and Lyon (1996) to simulate the entire distribution of future income. We show that our estimates of the distribution of future income are much less biased than the forecasted income distribution using the RW procedure in Graham (1996a, 1996b, 2000). For example, our estimates of future taxable income volatility range from $95 \%$ to $99 \%$ of actual future values (as compared to $37 \%$ to $62 \%$ for the historical income volatility approach described above).

Using our NP approach to estimating MTRs, we re-examine the evidence on whether firms establish debt levels to efficiently use the benefits from interest tax deductions. In particular, we analyze Graham's (2000) "kink" analysis, which estimates the amount of interest expense a firm could pay and continue to receive full marginal tax deductions. Graham's results suggest that a large fraction of firms uses debt conservatively, and could add significant amounts 
of debt to their capital structure and continue to receive incremental interest tax shields at the top statutory tax rate. However, because Graham's results rely on MTRs that are estimated using downwardly biased estimates of future income volatility, profitable firms in his analysis will tend to remain profitable in spite of increases in interest expense, and therefore, will have upwardly biased kink measures. Re-examining Graham's (2000) kink analysis using our NP income simulation, we find that most firms (71\%) operate their debt policy on the downward sloping portion of their tax benefit curve (i.e., they would not receive full tax deductions for an additional dollar of interest expense). The comparable figure is $42 \%$ of firms in Graham's (2000) analysis. Similarly, we find that only $11 \%$ of firms, as compared to $33 \%$ of firms in Graham's (2000) analysis, could increase their debt by $200 \%$ and still earn tax benefits at the top statutory rate. Overall, our results imply that relatively few firms could add substantial debt and still earn tax benefits at the top statutory rate. Further, for the small proportion of firms that do appear to be able to profitably add substantial debt, we find that the tax benefits foregone by these firms are substantially smaller than the benefits shown in Graham (2000). We then corroborate our inference on the misclassification of kinks in Graham (2000) by showing that firms would likely experience substantial increases in expected distress costs if leverage was increased to Graham's kink levels.

Finally, we provide evidence suggesting that firms which appear underlevered differ from other firms in ways that shed light on these firms' seemingly conservative debt policy. Two key findings are that apparently underlevered firms appear to have non-debt tax shields that are not recorded in firms' financial statements and have attributes consistent with relatively low debt capacity. Specifically, we find that the apparently underlevered firms have greater non-debt tax shields stemming from lower-taxed foreign income, greater use of stock option compensation, 
and greater tax credits owing to membership in high tech or pharmaceutical industries. Further, similar to Graham (2000), we provide some support for the notion that apparently underlevered firms may be less able to support substantial debt, due to higher expected agency conflicts and/or expected distress costs stemming from greater growth opportunities and lower operating stability.

In summary, our improved estimates of MTRs can assist our understanding of capital structure and payout policy choice, cost of capital and investment policy, compensation, and, of course, tax strategy. In this paper, we emphasize the implications of our MTRs for the "underleverage puzzle," a topic which has generated considerable interest among researchers. For example, Molina (2005) and Almeida and Philippon (2007) develop models in which very large estimates of distress costs explain the apparent underleverage suggested by the tax benefit calculations in Graham (2000). Our findings add to this debate by significantly lowering the distress costs necessary to justify firms' existing debt policy. That is, by documenting that most firms would gain only small interest tax shields by taking on additional debt, our findings raise the distinct possibility that firms do, in fact, choose efficient levels of debt.

As a caveat, we note that for applied and instructional purposes, our cross-sectional approach to estimating marginal tax rates is somewhat more work and therefore more costly than the Graham/Shevlin MTR. However, our results suggest that this cost is worthwhile for researchers or practitioners who want accurate estimates of marginal tax rates.

The remainder of our paper is organized as follows. In the next section, we describe our sample. We discuss the RW income simulation and examine its ability to predict future income in Section 3. In Section 4, we introduce our improved income simulation and show that it has less bias in predicting the distribution of future income. In Section 5, we compare MTRs 
computed with the two methods, and in Section 6, we compare kinks computed with the two methods. In the final section, we conclude.

\section{Sample selection and data description}

We use firms with available annual Compustat data from 1980 to 2007. From this group, we exclude banks, insurance companies, real estate investment trusts (“REIT"), royalty trusts, patent trusts, and American depository receipts (“ADR"). We exclude foreign registrants from our analysis because these entities' tax rates are functions of their home countries' tax regimes. Likewise, REITs are pass-through entities that pay no corporate taxes. Concepts of leverage are different for banks and insurers, which often have 10-to-1 debt-to-equity ratios. In addition, the data needed to compute taxable income are frequently missing for these firms (e.g., deferred taxes). ${ }^{1}$ In order to estimate the drift and standard deviation of income, we follow Graham, and require that at least three years of taxable income be available for a firm to be included in the sample. This sample-selection procedure yields 157,513 firm-year observations.

Following Graham, we focus on two versions of taxable income before interest expense. The first measure is taxable income before interest expense including transitory items such as special items, extraordinary items, and discontinued operations. This measure is the estimate of income ("taxable income") on which a firm actually pays taxes. That is, income (loss) due to special items, extraordinary items, and discontinued operations is taxable (tax-deductible). In Appendix A, we discuss our estimates of taxable income, including three improvements we make to the estimation of taxable income that differ somewhat from Graham's computations. Finally, because transitory items are typically non-recurring, they are unlikely to be helpful in

\footnotetext{
${ }^{1}$ Our inference is unaffected if we follow Graham (2000) and include these firms in our analysis, and set missing deferred tax items to zero when necessary.
} 
predicting future income. We therefore follow Graham and use taxable income before interest and before transitory items ("taxable income before transitory items") as the second measure of taxable income and the basis of our model used to forecast future income.

Much prior research on accounting income shows that extreme positive and negative income amounts mean-revert, and that mean reversion is greater for negative income years than for positive income years (see, for example, Hayn, 1995, and the references therein). To capture this potential mean reversion, we divide the data into groups based on the magnitude of current period income. To do this, we rank year $t-2$ taxable income before transitory items scaled by average total assets, and form two equal-sized negative taxable income subsamples and four equal-sized positive taxable income subsamples. Using these year $t$-2 cut-offs, we divide current year firms based on taxable income before transitory items at year $t$ scaled by average total assets. We form cut-offs based on past data and then sort on current data in order to avoid lookahead bias in our tests below.

Table 1 provides descriptive statistics on the properties of taxable income across these income groups. Each value in the table is determined by first computing that variable's median for each year (from 1980 to 2007), and then taking the average of the median values. To compare observations across differently sized firms, we scale all variables in the table by average assets at time $t$. In column 2, we show the median for the partitioning variable, taxable income before transitory items for the current year. Column 3 shows the current year change in taxable income before transitory items. In column 4, we show the difference between next year's taxable income after transitory items and this year's taxable income before transitory items. Comparison of columns 3 and 4 shows that there is substantial mean reversion in taxable income as firms with negative changes in year $t$ have very positive changes in year $t+1$, and vice versa. 
In columns 5 and 6 , we report the mean $\left(\mu_{t}\right)$ and volatility $\left(\sigma_{t}\right)$ of the change in taxable income before transitory items, which we compute following Graham (2000) and as discussed in the next section. Comparison of columns 4 and 5 provides descriptive evidence of our prediction above: the RW income simulation appears to perform poorly when there is sizable mean reversion. For example, in the very low-income group, the next year's actual median income change scaled by assets is $8.8 \%$, while the RW predicts $0.0 \%$, and in the very high-income group, the next year's actual median income change is $0.0 \%$ of assets, while the RW predicts $1.9 \%$.

\section{Evaluation of the random-walk income simulation}

The random-walk (RW) income simulation estimates the distribution of the level of future taxable income ( $T I)$ using a firm-specific random walk with drift specification:

$$
T I_{t+1}-T I_{t}=\hat{\mu}_{t}+\hat{\sigma}_{t} z_{t+1},
$$

where the dollar drift term, $\hat{\mu}_{t}$, and the dollar standard deviation of income shocks, $\hat{\sigma}_{t}$, are estimated using historical data over the life of the firm up to time $t$. (We have omitted the firm subscript for parsimony.)

To estimate the drift and standard deviation, we follow Graham (1996a, 1996b), and use all available taxable income either over the entire life of the firm, or beginning in 1973, whichever is later. For example, if a firm in 1980 has data back to 1973, it has eight income realizations from 1973 to 1980 , and seven income changes. For this firm, we measure $\hat{\mu}_{t}$ as the average change in income for the period ending 1980 and $\hat{\sigma}_{i}$ as the standard deviation of these income changes. Following Graham (2000), if the computed $\hat{\mu}_{t}$ is less than zero, we set it to zero. 
The random-walk model posits that firm income will increase by a constant amount $\left(\hat{\mu}_{t}\right)$ each year and will have constant standard deviation $\left(\hat{\sigma}_{t}\right)$ over time. However, because the typical firm's investment base is expected to grow over time, we expect that income and income volatility will grow over time, and that therefore $\hat{\mu}_{t}$ and $\hat{\sigma}_{t}$ will, on average, underestimate the mean and standard deviation of future income. In addition, as discussed above, we expect conditional biases to occur due to mean reversion.

In Panel A of Table 2, we examine the performance of the RW income simulation in predicting the distribution of pre-financing taxable income five-years ahead (this table also includes results for our NP approach, which we describe below). When we restrict the sample to have five-year-ahead income, we obtain 88,729 firm-years from 1980 to 2002 . We focus on fiveyear-ahead income for parsimony, but the results are very similar for one-year-ahead and twoyear-ahead forecasted taxable income distributions. We compare the distribution of future taxable income generated by the RW income simulation with the distribution of actual future taxable income. For each sample firm, we compute $\hat{\mu}_{t}$ and $\hat{\sigma}_{t}$, and make 100 draws from this assumed distribution to generate a distribution of simulated future taxable income for each firm. ${ }^{2}$ If the RW income simulation accurately predicts the distribution of future taxable income, then the simulated income (standard deviation) should be an accurate predictor of the level (standard deviation) of actual taxable income in both the full sample and in subsamples where taxable income is expected to mean-revert.

Column 1 of the first row in Panel A shows that the median forecast errors (computed as actual taxable income at time $t+5$ minus forecasted taxable income at time $t+5$ divided by

\footnotetext{
${ }^{2}$ By construction this distribution is normal with mean $\hat{\mu}_{t}$ and standard deviation $\hat{\sigma}_{t}$. We draw from the distribution rather than compute the exact cut-offs from the normal distribution in order to parallel our results in Section 4 below.
} 
average total assets at time $t$ ) are small, with an (insignificant) value of $-0.1 \%$ of average assets. However, the RW income simulation underestimates the standard deviation of future taxable income. The left-hand graph in Panel A of Fig. 1 illustrates the empirical distributions of actual and RW income. The RW distribution has a high peak and a narrow standard deviation compared to actual income. The remaining columns in the first row in Panel A of Table 2 confirm that these visual differences are statistically significant. Actual taxable income too frequently falls outside the 5\% tails of the RW income distribution and too infrequently falls in the middle $50 \%$ of the distribution. As a summary measure of how well the RW income simulation forecasts the variability of future income, column 5 provides the ratio of the standard deviation of simulated future income to the standard deviation of actual future income. The RW simulated standard deviation of future income is only $52.6 \%$ of the actual standard deviation.

In the left-hand graphs of Panels B and C of Fig. 1, we provide similar graphical summary results for the extreme low-income and high-income subsamples of the data presented in Panel A. The purpose of this analysis is to explore the accuracy of the RW income simulation in non-random subsamples where taxable income is likely to have a substantial mean-reverting component. For low return-on-assets (ROA) firms, the left-side graph of Fig. 1, Panel B illustrates that the RW produces future income forecasts that are too low with a standard deviation that is too small. Panel B of Table 2 indicates that the RW income simulation generates a large and positive median forecast error of $19.3 \%$, indicating that actual taxable income is greater than forecasted taxable income. This is intuitive. The RW income simulation essentially forecasts next year's income as this year's income with a drift. Therefore, because large losses tend to be temporary, the best expectation of next year's income for a large loss firm is likely much higher than this year's income. As in the full sample, the RW income simulation also 
underestimates the standard deviation of future taxable income in the low-income subsample, with an estimated value of $61.6 \%$ of the true standard deviation. These values are statistically different at a $p<0.05$ level from the expected level under the null.

For high ROA firms, the left-side graph of Fig. 1, Panel C illustrates that the RW produces future income forecasts that are too high with a standard deviation that is too low. Thus, the results in Panel $\mathrm{C}$ for the high-income subsample are similar to Panel B but with differences in the opposite direction. Panel $\mathrm{C}$ of Table 2 indicates that the RW income simulation generates a significant negative median forecast error of $-9.4 \%$, indicating that actual taxable income tends to be less than forecasted taxable income. Again, the RW income simulation severely underestimates the standard deviation of future taxable income with an estimated value of only $37.3 \%$ of the true standard deviation. These values are statistically different at a $p<0.05$ level from the expected level under the null. Overall, Fig. 1 and Table 2 illustrate that the RW income simulation does not accurately capture the distribution of future taxable income, and that the random-walk does worse when there is mean reversion in future taxable income. While these differences are statistically significant, we show in our analysis below that they are also economically significant.

\section{An alternative approach to simulating future taxable income \\ 4.1. Motivating a non-parametric alternative approach}

Modeling the distribution of the level of future taxable income is a difficult problem for several reasons. First, most research concentrates on predicting future scaled income [e.g., income scaled by sales or income scaled by assets as in Barber and Lyon (1996)] as opposed to the dollar level of income. Second, unlike many prediction exercises in which it is only 
important to generate an accurate estimate of the center of the distribution (e.g., analyst forecasts), in a simulation of the MTR, it is also very important to generate accurate estimates of higher moments of the distribution, such as the standard deviation. Finally, although other literature uses analysts' forecasts for future earnings expectations, analysts' forecasts are problematic in our setting. In addition to the concern that forecasts are available for only a subset of firms, analysts do not forecast taxable income (which is necessary to estimate the MTR), and prior research has shown that analysts' long-term forecasts are systematically biased (e.g., Dechow and Sloan, 1997, p. 15).

We develop an alternative method of simulating future taxable income for use in computing the MTR. We use an income simulation that matches a given firm to similar firms based on size and profitability. We draw a return-on-asset and asset-growth number from these similar firms, and we then forecast future assets by multiplying current assets by asset-growth and forecast future income by multiplying forecast ROA by forecast assets.

As an alternative to our non-parametric method, one might develop a better firm-specific time-series model for the level of income. For example, one could attempt to address the stationarity and mean-reversion issues in Eq. (1) by using some form of changes model and/or an autoregressive (AR) process. Graham and Kim (2009) do this by estimating a pooled AR(1) model for taxable ROA. In an analysis similar to our Table 2, they find that their AR(1) model is more accurate than the random-walk in estimating the standard deviation of taxable income, but that it continues to underestimate the standard deviation of taxable income.

Our approach builds on the Barber and Lyon (1996) matched firm approach for generating expected future performance for a given firm. Their simulation results show that 
matching on size and prior performance at time $t$ generates a well-specified model of expected performance of a firm beginning at time $t+1$, as they summarize on p. 397:

The one method that yields test statistics that are well specified in every sampling situation that we analyse is to match sample firms to control firms on size and pre-event performance, without regard to industry.

The idea behind this approach is that future profitability, including mean reversion in income, is a function of both current performance and firm size.

But our objective, modeling the level of future income for a tax simulation, faces a further problem. In addition to estimating the mean of future performance, we also need to estimate other distributional characteristics such as standard deviation, skewness, etc. Following Barber and Lyon (1996), we reason that if firms of similar performance and size share similar mean future performance, then it seems reasonable to think that the distribution of the changes in these firms' future performance will be similar as well (our results below serve as an indirect test of this hypothesis).

\subsection{Implementing the non-parametric approach}

Another of our objectives is to model an ex ante expectation of performance from the perspective of firm managers at time $t$, when they are forming MTRs based on their expectations of future income. We assume that they know year $t$ income for their own firm, but can only observe year $t$ - 1 income for other firms. Therefore, they form their expectations of future income by observing how $t-2$ income maps into $t-1$ income for other firms of similar profitability and size.

To implement our NP approach for a given firm at time $t$, we simulate future income in times $t+1$ through $t+22$ following five steps (see Fig. 2). In the first step, we divide all firms with available data at time $t-2$ into 30 performance-size bins. Specifically, at year $t$ - 2 , we rank firms into two negative income groups and four positive income groups (similar to the procedure in 
Table 1). Our ranking variable is year $t$-2's return-on-assets $\left(\mathrm{ROA}_{t-2}\right.$ measured as taxable income before transitory items for year $t-2$ divided by average total assets, Ave $\left.\left(\mathrm{TA}_{t-2}\right)\right){ }^{3}$ Within each of these six groups, we further divide the firms into five size quintiles based on ranking average assets at year $t-2$ (that is, Ave $\left.\left(\mathrm{TA}_{t-2}\right)\right)$. The resulting procedure yields 30 performance-size bins; ten negative income-size groups with roughly equal numbers of observations, and twenty positive income-size groups with roughly equal numbers of observations. For each firm in these 30 performance-size bins, we collect data on the next year's change in return-on-assets $\left(\mathrm{ROA}_{t-1}\right.$ $\left.\mathrm{ROA}_{t-2}\right)$ and growth in total assets measured as Ave $\left(\mathrm{TA}_{t-1}\right) / \operatorname{Ave}\left(\mathrm{TA}_{t-2}\right)$. Thus, given performance and size at $t-2$, the bins provide the empirical distributions of changes in one-year-ahead performance and size. Note that the quintile rankings, and relative size cut-offs, are based on the dollar value of average assets at the end of year $t-2$. Our simulation procedure matches firms to bins by size beginning in year $t-1$ and through $t+21$. To address the fact that dollar assets typically grow over time, and to appropriately gauge the relative sizes, we grow the bin size cutoffs each year by compounding the median actual growth rate from $t-3$ to $t-2$ for all of the firms in that year's bins. ${ }^{4}$ For example, to match a firm's assets to a size bin at $t$-1, we grow the bin cut-offs by $(1+\text { median growth rate })^{2}$.

We note that this simulation procedure requires that each bin firm have a year of "future" taxable income, i.e., the bins are formed using data at time $t-2$ but require income data at time $t$ 1. This requirement that the bin firms survive for a year after sorting is consistent with the

\footnotetext{
${ }^{3}$ An alternative grouping approach would be six equal-sized groups ranked on ROA where one of the six groups contains both positive and negative ROA observations. We partition the data first on positive and negative current period taxable income because mean reversion is greater for negative income years than for positive income years (e.g., Hayn, 1995). Further, we use more positive ROA than negative ROA groups (four vs. two) because there are substantially more positive ROA observations than negative ROA observations.

${ }^{4}$ We recognize that using the median growth rate to grow the size cut-offs of the bins is somewhat ad hoc. Therefore, we estimate the sensitivity of our inference to lower and higher growth of the size parameters. Our inference is the same if we assume no growth in the cut-offs of the bins or if we grow the cut-offs at twice the median rate.
} 
control firm approach of Barber and Lyon (1996) and others that require future income. A potential concern with this approach is that performance characteristics of surviving firms may differ in such a way from the general population as to bias our inference about MTRs. Sensitivity analysis using imputed income data from propensity score matching suggests that survivor issues do not affect our inference. ${ }^{5}$

The second step in simulating future taxable income for a given Firm I in year $t$, is to identify the performance-size bin that matches Firm I's current year return-on-assets and average total assets (i.e., $\mathrm{ROA}_{t}$ and $\mathrm{Ave}\left(\mathrm{TA}_{t}\right)$ ). Specifically, we identify the year $t$-2 performance-size bin that Firm I would have fallen into based on its year $t$ return-on-assets and average total assets. Next, we randomly draw a Firm $\mathrm{M}_{1}$ from the bin and use Firm $\mathrm{M}_{1}$ 's change in return-on-assets $\left(\Delta \mathrm{ROA}_{t-1}=\mathrm{ROA}_{t-1}-\mathrm{ROA}_{t-2}\right)$ and asset growth $\left(\operatorname{Ave}\left(\mathrm{TA}_{t-1}\right) / \operatorname{Ave}\left(\mathrm{TA}_{t-2}\right)\right)$ as the forecast of Firm I's one-year-ahead change in return-on-assets $\left(\mathrm{ROA}_{t+1}-\mathrm{ROA}_{t}\right)$ and asset growth $\left(\operatorname{Ave}\left(\mathrm{TA}_{t}\right) / \operatorname{Ave}\left(\mathrm{TA}_{t-1}\right)\right)$. In the fourth step, we add this change in return-on-assets to Firm I's $\mathrm{ROA}_{t}$ to obtain forecasted $\mathrm{ROA}_{t+1}$ (i.e., $\mathrm{ROA}_{t+1}=\Delta \mathrm{ROA}_{t+1}+\mathrm{ROA}_{t}$ ). Similarly, we multiply average total assets, Ave $\left(\mathrm{TA}_{t}\right)$, by the forecasted asset growth to obtain forecasted assets at the time $t+1$, Ave $\left(\mathrm{TA}_{t+1}\right)$. Our forecast of the dollar level of Firm I's one-year-ahead taxable income results from multiplying this average total assets, Ave $\left(\mathrm{TA}_{t+1}\right)$, by forecasted $\mathrm{ROA}_{t+1}$ (i.e., taxable income $\left._{t+1}=\operatorname{Ave}\left(\mathrm{TA}_{t+1}\right) * \mathrm{ROA}_{t+1}\right)$.

To obtain taxable income at $t+2$, we repeat the process. We then re-match Firm I into one of the 30 performance-size bins based on Firm I's forecasted level of ROA for year $t+1$ and

\footnotetext{
${ }^{5}$ To assess the sensitivity of our results to survivor issues, we impute the income data for the missing firm-years by matching to non-missing firms using propensity score analysis. Specifically, following a procedure similar to that in Rosenbaum and Rubin (1983), we fit a parsimonious logit model that models the probability that year five income is missing as a function of size (log assets), profitability (EBIT/assets), and book leverage (debt/assets). We fit the model each year by income and size group, and we use the predicted probability to match (with replacement) each missing firm to a non-missing firm that has the closest predicted probability. In untabulated results, we find that this data imputation procedure does not affect our assessment of the mean and standard deviation biases in the RW income simulation.
} 
average total assets as of the end of year $t$. We then draw another Firm $\mathrm{M}_{2}$ from the newly matched bin and forecast $\mathrm{ROA}_{t+2}$ and asset growth $\left(\operatorname{Ave}\left(\mathrm{TA}_{t+2}\right) / \operatorname{Ave}\left(\mathrm{TA}_{t+1}\right)\right)$ and compute a forecast for Firm I's year $t+2$ dollar level taxable income $\left(\mathrm{TI}_{t+2}\right)$. We iterate this process to compute the dollar level of taxable income for all future years needed to compute the MTR. We then repeat this simulation procedure 50 times to obtain an estimate of each firm's expected MTR.

We note that the observations in the 30 original performance-size bins are held constant throughout the simulation. Thus, the simulation makes an implicit assumption that the distribution of one-year-ahead ROA and asset growth over the MTR simulation horizon is stationary as a function of current period performance and relative size. So long as the distribution that maps current ROA and asset size into future ROA and asset size is reasonably stationary over time, this procedure should yield a simulation in which the distribution of the simulated data approximately matches the distribution of the actual data.

\subsection{Evaluating the non-parametric approach}

As with the RW distribution, we graphically illustrate differences between the actual distribution and the NP distribution using the right-hand graphs in Panels A, B, and C of Fig. 1. From the graphs, it appears that the NP distribution better matches the actual distribution than does the RW distribution. To more directly test the extent to which our NP income simulation matches the distribution of the actual data, in Table 2 , we empirically compare the distribution of future taxable income generated by our NP procedure with the distribution of actual future taxable income (analogous to the comparisons described above for the RW income simulation).

Column 1 of the second row of Panel A of Table 2, indicates that the full-sample median NP forecast error is (insignificantly) negative at $-1.7 \%$, indicating that forecasted taxable income 
is, on average, somewhat greater than actual taxable income. Columns 2 through 5 indicate that the NP income simulation appears to perform quite well in estimating the standard deviation of future taxable income. The estimated standard deviation is $98.8 \%$ of the actual standard deviation, which is not significantly different.

In Panels $\mathrm{B}$ and $\mathrm{C}$ of Table 2, we tabulate results for high-income and low-income subsamples of the data presented in Panel A of Table 2. As noted above in the discussion of the $\mathrm{RW}$ income simulation, the purpose of this analysis is to explore the accuracy of the NP income simulation in non-random subsamples where taxable income is likely to have a substantial meanreverting component.

Panel B of Table 2 indicates that in the low-income subsample, the NP income simulation generates a more negative and significant median forecast error $(-10.1 \%)$ than in the full sample. However, these forecast errors are smaller in absolute magnitude than the forecast errors reported for the RW income simulation. In addition, the NP income simulation does well in estimating the standard deviation of future taxable income. The estimated standard deviation is $96.0 \%$ of the actual, and is again not significantly different.

The results in Panel $\mathrm{C}$ of Table 2 indicate that the NP income simulation produces taxable income forecasts for the high-income subsample that are also more accurate. The median NP forecast error is (insignificantly) positive at $2.7 \%$. The NP income simulation also appears to perform well in estimating the standard deviation of future taxable income. The estimated standard deviation is $95.4 \%$ of the actual standard deviation, which is not significantly different. Overall, the results in Table 2 (illustrated in Fig. 1) show that although the NP 
simulation is not perfect, it estimates the level, standard deviation, and mean reversion of future taxable income more accurately than the RW income simulation. ${ }^{6}$

\section{Computation of marginal tax rates}

In this section, we compare descriptive statistics on MTRs computed for a broad sample of firms from 1980 to 2007 using both our NP income simulation and the RW income simulation. To estimate the MTR using the RW income simulation, we replicate Graham's prefinancing (before interest expense) MTRs using the procedure described in Graham (1996a, 1996b) and Graham, Lemmon, and Schallheim (GLS, 1998). Replication of the Graham (1996a, 1996b) and GLS (1998) procedure is non-trivial and requires developing a fairly complex algorithm that incorporates not only estimates of future taxable income, but also firm-specific historical data as well as nuances of the corporate tax system. ${ }^{7}$ Appendix A details how we estimate taxable income, including our modifications as compared to Graham (1996b).

In Table 3, we summarize and provide descriptive statistics on pre-financing MTRs. To ease exposition, we add the prefixes $\mathrm{NP}_{-}$and $\mathrm{RW}_{-}$to refer to the $\mathrm{NP}$ marginal tax rates generated by our NP procedure and our replication of Graham's marginal tax rates generated by

\footnotetext{
${ }^{6}$ As with the results for the RW in Table 2 discussed above, we conduct sensitivity analyses for the NP results in Table 2 to ensure that our inferences are not influenced by survivorship. Using the methodology described above in Footnote 5, we examine the survivorship bias in the NP income simulation by incorporating imputed data using propensity score matching. The results (not tabulated) indicate that survivorship does not appear to affect our inference that the NP income simulation is less biased that the RW income simulation.

${ }^{7}$ We include the ITC and NOLs as described in Graham (1996a) and GLS (1998). However, we ignore the alternative minimum (AMT) tax. The AMT is estimated in parallel with the regular tax, but with different definitions of taxable income, different exemptions and different rates. The intent of the AMT is to ensure that profitable companies pay at least some federal income tax by subjecting taxpayers to a $20 \%$ tax on a broader definition of taxable income. Financial statement information (i.e., Compustat) does not provide the data necessary to estimate alternative minimum taxable income. Among other things, AMT depreciation is missing. Graham (2000) incorporates the AMT by subjecting regular taxable income to the $20 \%$ AMT tax rate. If a firm has a greater liability using the $20 \%$ rate than the regular statutory tax rates, then the AMT liability is used to estimate the firms' MTR. Note that this methodology effectively subjects only companies with very low taxable income $(\$ 50,000$ or $\$ 75,000$ depending upon the time period) to the AMT since this is the only income range with statutory rates less than $20 \%$. However, in reality all firms are potentially subject to the AMT, not just small firms. Since it is not possible to apply the AMT consistently for all firms, we ignore it in our MTR calculations.
} 
the RW procedure, respectively. For completeness, we also report the pre-financing MTRs that John Graham provides on his Web site, WEB_MTR.

Panel A of Table 3 shows the mean pre-financing MTR is $29 \%$ for the NP MTRs and $28 \%$ for the RW MTRs, indicating that, on average, our MTRs are similar to the RW MTRs. Similarly, the mean of the pre-financing MTRs from Graham's Web site is 29\%. Panel A of Table 3 also shows the distribution of MTRs. The MTRs range from $0 \%$ to $51 \%$. Although the highest statutory rate during our sample period was $46 \%$, a firm can have a higher MTR than the top statutory rate because of the graduated rate structure. This means that at low levels of income, firms face lower statutory tax rates than at higher levels of income, but there is a "catchup" zone in which a high effective rate brings the firm to an average rate equal to the "top" statutory rate. ${ }^{8}$ The three MTRs have similar distributions across the sample firms, except that the NP MTRs exhibit somewhat fewer very low MTRs. Panel B of Table 3 presents the data as a percentage of the statutory tax rates. A substantially greater percentage of the NP MTRs are below the statutory rate $(85 \%)$ as compared to the RW and WEB MTRs $(59 \%$ and $62 \%$, respectively). The average yearly rank correlation between the NP MTRs and the RW MTRs is 0.81 (untabulated).

As argued above, we expect the NP and RW simulation procedures to generate different MTRs as a function of profitability. Table 4 presents average MTRs across firms with different levels of profitability. Specifically, we present pre-financing MTRs for the six ROA groups that we use in Table 1. For each group, we present the mean MTR for the NP, RW, and WEB MTRs, as well as the mean differences in the MTRs across the three approaches.

\footnotetext{
${ }^{8}$ Consider the 1986 graduated rate structure. Although the top tax rate is $46 \%$, taxable income between $\$ 1$ million and $\$ 1.405$ million is taxed at a rate of $51 \%$. This taxable income band effectively subjects all taxable income below $\$ 1.405$ million to an average rate of $46 \%$ percent. In addition, a firm may have a marginal tax rate that exceeds any tax rate in the current rate structure because NOLs can be carried back to earlier tax regimes (i.e., a net operating loss (NOL) generated in 1987 can be carried back to 1984).
} 
In the negative ROA bins, the NP MTRs are greater than the Graham simulated MTRs, with an average difference of about 5\%. These greater MTRs for the NP simulation in the lowincome subsamples are expected. Because the RW simulation generates too little future income volatility, when current firm profitability is negative, the RW simulation is less likely to forecast future states with positive income that allow the firm to use the tax shield from current period losses. The opposite effect occurs for firms in the high profitability bins. In the high ROA bins, the NP MTRs are lower than the RW MTRs, with average differences of $-1.2 \%$ and $-1.8 \%$ depending on the bin. These lower MTRs for the NP simulation are again expected. Because the RW simulation generates too little future income volatility, when current firm profitability is high, the RW simulation is less likely to forecast future states with negative income that would prevent the firm from paying the maximum tax rate on an incremental dollar of income in the current period.

\section{Evaluating the marginal tax benefit "kink" and area under tax benefit curve}

The debt capacity measures computed using Graham's (2000) MTRs generate the appearance that a large fraction of firms are underutilizing the tax benefits of debt. In particular, Graham's (2000) analysis suggests that 44\% of firms could double their debt and still receive full tax benefits from interest deductions (p. 1903 and Table III). Molina (2005, p. 1427) motivates his paper with the observation that "Graham (2000) finds that by leveraging up to the point that tax benefits begin to decline, a typical firm could add $7.5 \%$ to market value, after netting out the personal tax penalty." This inference about capital structure policy stems from Graham's "kink" analysis, which estimates the amount of interest expense a firm could pay before it incurs diminishing marginal tax benefits. Intuitively, the kink is the point after which the tax benefit of 
interest is less than the top statutory tax rate. ${ }^{9}$ For example, a firm with a kink of 2.0 is expected to be able to double its interest expense and double its tax benefits earned at the top statutory rate, but interest beyond this point would add tax shield benefits at a lower rate. Similarly, a firm with a kink of one is expected to earn tax benefits at the top statutory rate on its existing level of debt, but lower tax benefits per dollar on any additional interest expense, and a firm with a kink of zero is expected to receive tax benefits at less than the top statutory rate on its first dollar of interest expense.

\subsection{Comparing the tax benefit "kink" across MTR measures}

In Table 5, we re-examine Graham's kink analysis using the NP MTRs. As noted above, we expect that some portion of the seemingly large, underutilized tax benefits of debt could stem from Graham's MTRs overestimating the kink. Specifically, when the RW income simulation standard deviation of taxable income is too low, profitable firms will tend to remain profitable in spite of increases in interest expense, and therefore, will have upwardly biased kink measures.

The first two columns of Panel A of Table 5, which are computed from Graham's Table II, show the distribution of kinks reported in Graham (2000), for the period 1980 to 1994. The average kink of the sample firms is 2.36 . Further, $58 \%(33 \%)$ of the sample firms have kinks greater than or equal to 1.0 (3.0), suggesting that most firms could add debt to the capital structure (in many cases substantial amounts of debt) and still earn tax shields on interest at the top statutory rate. The next two columns of Table 5 retabulate the kink using our replication of

\footnotetext{
${ }^{9}$ As detailed in Appendix B, we follow Graham (2000, p. 1915) and van Binsbergen, Graham, and Yang (2007, footnote 5) and define the "kink" as the first interest increment at which the firm has a decline in its marginal tax rate of at least 50 basis points. Another economically meaningful interpretation of kink is the first increment at which the firm has a post-financing marginal tax rate that is at least 50 basis points lower than the top statutory tax rate. All of our inferences hold when the analysis is conducted using this kink definition.
} 
Graham's RW income simulation MTRs ("RW kink"). The mean RW kink is 1.87, which is somewhat lower than the 2.36 average kink reported in Graham (2000). ${ }^{10}$

The final two columns of Panel A of Table 5 present kinks computed with the NP MTRs ("NP kink"). The mean NP kink is 0.98 , which is $48 \%$ smaller than the mean RW kink. Table 5 also indicates that a much smaller fraction of firms have NP kink measures greater than or equal to 1.0 (29\% of NP kinks vs. $49 \%$ of RW kinks), and only $8 \%$ of firms have NP kinks greater than 3.0 (as compared to $19 \%$ of the RW kinks). These results suggest that most of the sample firms have chosen a capital structure where their interest tax shields are already on the downward sloping portion of the marginal benefit curve. That is, if a firm with a kink less than one were to add a dollar of interest expense, the expected tax shield would be less than the firm's prefinancing MTR. This finding suggests that prior results overestimate the underused tax benefits of debt, and that these results may have been influenced by the use of RW income simulation MTRs that underestimate the volatility of expected future taxable income. Panel B of Table 5 reports that inferences using the full 1980-2007 sample RW and NP kinks are very similar to those for the earlier subsample.

In Table 6, columns 1-3, we compare the RW kinks with the NP kinks, sorting by income group. The greatest difference in the kink measures occurs in the two highest income groups, where Panel C of Table 2 shows that the RW income simulation forecasts income that is greater than actual income, and forecasts a standard deviation that is smaller than the actual standard deviation.

\footnotetext{
${ }^{10}$ A potential explanation for this lower kink is that we exclude ADRs, banks, insurers, and REITs from our sample. As noted above in Section 2, we exclude foreign registrants because these entities' tax rates are functions of their home countries' tax regimes. Likewise, REITs are pass-through entities that pay no corporate taxes. Concepts of leverage are different for banks and insurers, which often have 10-to-1 debt-to-equity ratios. In addition, the data needed to compute taxable income are frequently missing for these firms.
} 
Although our evidence in Table 2 above suggests that the NP simulation generates more accurate forecasts and standard deviations than the RW simulation, it is not perfect and is somewhat inaccurate in the two extreme income groups. To address the concern that the results in Table 6 may be driven by these imperfections in the NP simulation, we now provide results corroborating our evidence of smaller underutilized tax benefits of debt that do not rely on the NP simulation. For reasons discussed above, there is no obvious way of correcting the RW simulation ex ante, so instead we correct it ex post using perfect foresight of future means and standard deviations. To do this, we compute kinks for a typical firm in each income group using the income group's median ROA, $\mu_{t}$, and $\sigma_{t}$. We calculate the median $\mathrm{ROA}_{t}, \mu_{t}$, and $\sigma_{t}$ as the average of the annual median values. We then recompute the kinks using the RW income simulation with forecasts of $\mu_{t}$ and $\sigma_{t}$ that are corrected for the errors in mean and standard deviation that are summarized in Table $2 .{ }^{11}$ This procedure is useful to assess the accuracy of the kink, but is not a feasible method for generating ex ante MTRs and kinks. This procedure uses perfect foresight of future income distributions. In contrast, Graham (1996b) and Graham and Kim (2009) compute perfect foresight MTRs using a single realization of future income. ${ }^{12}$

Columns 4 and 5 of Table 6 show the results of this analysis. The column headed "Kink: RW income forecast" shows the results for the median firm using the RW forecast. Not

\footnotetext{
${ }^{11}$ Specifically, we also use the one-year and two-year values of the forecast error and simulated standard deviation to the actual standard deviation. We then compute an annualized error as the average (one-year median forecast error, two-year median forecast error/2, five-year median forecast error/5) and compute the average of the one-year, two-year, and five-year ratio of the simulated standard deviation to the actual standard deviation.

${ }^{12}$ Note, however, that to compute correctly a perfect foresight MTR or kink, one needs to proxy for perfect foresight of the distribution, not just a single realization from the distribution. As Graham (1996b, p. 206) suggests, an ideal perfect foresight rate is constructed by "integrating across all possible realizations of future taxable income." In contrast, Graham and Kim (2009) forecast perfect foresight MTRs calculated using a single realization of future income, and find that our NP method performs poorly in predicting this rate. We instead estimate a perfect foresight MTR calculated in the spirit of Graham (1996b). To estimate this rate, we average future MTRs for similar firms, where we define similar firms as those from the same size and income bins from above. In untabulated analysis, we find, consistent with our income forecasting results above, that the NP rate is a more accurate proxy for the perfect foresight MTR than the RW rate, and, as compared to the NP rate, the RW rate tends to be too low for low-income firms and too high for high-income firms.
} 
surprisingly, this kink is similar to the kink computed for the full sample using the RW forecast. The far-right column headed "Kink: Perfect foresight income forecast" shows a much smaller kink, that is only greater than 1.00 in the two most profitable groups. The magnitude of this perfect foresight kink is similar to that of the NP simulation kink computed for the full sample. Overall, these alternative kink results reinforce our inference that Graham's calculated kinks are too large, and that they are too large due to biases in the RW income simulation.

\subsection{Evaluating the net benefits of increased leverage}

As reported in Table 5, our NP income simulated MTRs result in kinks which suggest that firms may be less underlevered than previously indicated by the RW kink measures that rely on MTRs using the RW income simulation. In Table 7, we compare the RW and NP approaches to quantify the net benefits of increasing leverage up to the kink, where the benefits are net of the estimated costs of distress. A firm with a kink of 2.0, for example, is expected to be able to double its current interest expense and continue to achieve interest tax shields at the firm's prefinancing MTR. Increasing interest expense, however, will increase the probability that the firm cannot make these payments and will therefore increase the firm's expected costs of distress. We quantify the extra tax shield benefits from increasing leverage up to the kink, and also use the results in Molina (2005) and Almeida and Philippon (2007) to quantify the expected increase in distress costs from the increased leverage.

Table 7, Panel A shows a summary of the gross tax benefits, distress costs, and net benefits of increased debt for groups of firms ranked on the RW kink. Column 1 sorts firms into five RW kink groups: 1) kink less than one; 2) kink between one and two; 3) kink equal to two; 4) kink equal to three; and 5) kink greater than or equal to four. Columns 2 and 3 report the 
number and percentage of firms in each kink group (because we require data on market value, the sample size in Table 7 is reduced to 138,976 firm-year observations).

In columns 4 through 6 , we compare the RW and NP MTRs with respect to the expected percentage increase in the market value of assets (MVA), computed as the sum of the book value of debt plus market value of equity, stemming from an increase in interest expense that brings the firm up to its RW kink. We follow Graham and assume that existing interest expense consists of interest on debt and one-third of operating leases, and we measure the increase in interest expense over this existing interest expense. We follow Graham (2000) Eq. (2), and capitalize this incremental interest assuming it is perpetual and using the MTR net of the "personal tax penalty" related to personal tax rates on interest and equity. We express the value as a percentage of MVA. Column 4 presents the gross tax benefits from increasing leverage based on RW MTRs (e.g., for a firm with a kink of three, the gross tax benefit is $6.3 \%$ of MVA).

As discussed above, however, the RW MTRs overestimate the value of extra tax benefits from increased leverage because the NP tax benefit function typically starts to drop before the RW kink. In other words, the typical firm with a RW kink of 2.0 has an NP kink of 1.0, so the RW tax benefit function is too high once the NP kink is passed. We illustrate this point by calculating the tax benefit from increasing leverage to the RW kink, but using the NP benefit curve to compute tax benefits. This "corrected" tax benefit function is reported in column 5 and shows that the correct increase in MVA from an increase in interest expense to the RW kink is substantially less than the RW benefit function in column 4. Specifically, column 6 shows that the NP benefit measure is, on average, about $36 \%$ to $54 \%$ of the RW benefit measure depending on the kink level. Molina (2005) and Almeida and Philippon (2007) argue that, because Graham's estimates of distress costs are too small, he overestimates the extent to which firms are 
underleveraged. Our results complement the conclusions in those papers by documenting that another reason why Graham overestimates underleverage is because he overestimates the tax benefits of debt.

We combine the two results in columns 7 to 13 , where we work through a calculation of net tax benefits, which are tax benefits net of expected distress costs. We compute risk-adjusted distress costs following Almeida and Philippon (2007); the details of this computation are in Appendix C. Column 7 shows the firms' current book leverage, and column 8 shows the amount of book leverage firms would have to add to their capital structure assuming debt is increased to the RW kink. ${ }^{13}$ Column 9 shows the estimated increase in risk-adjusted distress costs (as a percentage of MVA) associated with the added leverage implied by the kink.

Columns 10 and 11 show results from using the RW MTRs to estimate the net benefit (or cost) estimated from increasing leverage to the kink, which is the difference between the RW additional benefit shown in column 4 and the incremental distress costs shown in column 9 . The average net benefits for the various kink groupings are between $-0.2 \%$ and $1.1 \%$ in column 10 , with column 11 showing that the proportion of values that are greater than zero ranges from $33.7 \%$ to $51.4 \%$ across the kink groupings. Columns 12 and 13 show results from using the NP MTRs to estimate the net benefit (or cost) estimated from increasing leverage to the kink, which is the difference between the NP additional benefit shown in column 5 and the incremental distress costs shown in column 9. As expected, the corrected net tax benefits are substantially

\footnotetext{
${ }^{13}$ To make firms comparable, and to be consistent with the tax benefit calculation that capitalizes deductions on interest on both debt and estimated interest on off-balance-sheet operating leases (i.e., one-third of rent expense), we compute the increase in total debt by capitalizing the interest that is added up to the kink. We capitalize this new interest by dividing it by the Moody's Baa bond yield, and add the resulting perpetuity value to existing debt. Note that the values in column 8 are somewhat greater than the multiple of leverage in column 7 implied by the kink. For example, beginning book leverage for a kink of two is $26.9 \%$, but the addition to leverage is $33.6 \%$. This occurs because beginning leverage does not include off-balance-sheet interest, while we assume new leverage is all on balance-sheet.
} 
lower than the net benefits using the RW MTRs, with positive net benefits for only $18.5 \%$ to $29.2 \%$ of the firms depending on the kink grouping.

In Panel B of Table 7, we present a parallel analysis to Panel A except that we sort firms on the NP kink (instead of sorting on the RW kink), and show a summary of the gross tax benefits (computed using the NP MTRs), risk-adjusted distress costs, and net benefits of increased debt for groups of firms that lever up to the NP kink. Consistent with our earlier findings in Table 5, columns 2 and 3 show a smaller percentage of firms in the kink $\geq 2$ groups as compared to the analogous RW kink $\geq 2$ groups. The remaining columns in Panel B show the gross tax benefits, increased risk-adjusted distress costs, and net benefits from increasing leverage to the NP kink. Similar to findings in columns 12 and 13 of Panel A, the NP kink results in fewer firms with positive net benefits when leverage is increased to the kink.

\subsection{Exploring the characteristics of high NP kink firms}

Overall, our results using the NP income simulation MTRs suggest that fewer firms appear underlevered than previously inferred from the RW kink measures that rely on MTRs using the RW income simulation. At the same time, a number of firms remain puzzling as they appear to be able to earn net benefits from adding debt to their capital structure (from Table 7, Panel B, column 10). Note further that column 10 of Table 7, Panel B understates the number of firms that could earn positive net benefits from adding some debt to their capital structure. This is because the computation suggesting a net cost to adding debt up to the kink does not imply that there are no marginal benefits to additional debt beyond a firm's current level of debt. For example, a firm with a kink of three might be able to double its debt with positive net benefits, but when it triples debt, the net benefits turn to zero (or become negative). 
In Table 8, we examine firms that appear to be underlevered in an attempt to better understand the characteristics of these firms and to explore the possibility that these firms might have sound economic reasons for not taking on additional debt (e.g., difficult-to-measure nondebt tax shields, lower debt capacity due to asset composition, etc.). We examine two groups of firms: 1) 8,070 firm-years with positive net benefits from doubling debt, where net benefits are computed as in Table 7 using the NP benefit curve (i.e., the incremental tax benefits from doubling debt less the increase in the distress costs from doubling debt),${ }^{14}$ and 2) 12,889 highkink firm-years with NP kinks $\geq 4$. Examining high-kink firms in addition to net-benefit firms allows us to check the robustness of our results when we relax the assumptions about default costs and personal taxes used in identifying the net-benefit firms. We compare these two groups of firms with a sample of firms that is less likely to be underlevered. Specifically, these are 53,747 firm-years in the most profitable two ROA groups (from Table 6) that have NP kinks $<2$. We use profitable, low-kink firms for the comparison sample because these firms have similar profitability to the firms that appear underlevered, but do not appear to have substantial amounts of unused debt capacity. The remaining rows of Table 8 provide descriptive evidence on the characteristics of these three groups of firms. Each value in the table is determined by first computing that variable's median for each year (from 1980 to 2007), and then taking the average of the annual median values. We compute significance levels for tests of differences in the medians using Fama MacBeth (1973) standard errors. ${ }^{15,16}$ Because the high-kink and positive net-benefits samples have similar characteristics, and similar differences with the low-kink

\footnotetext{
${ }^{14}$ This group includes 1,248 firms that have kinks greater than two but have no debt.

${ }^{15}$ The mean of annual differences in means is reported for dichotomous variables.

${ }^{16} \mathrm{We}$ obtain the same inference if we use a logit model that compares the apparently underlevered and comparison firms.
} 
sample, we combine our discussion of them, refer to them as the "apparently underlevered" firms, and note any differences between the groups.

We examine two broad categories of economic characteristics in Table 8. First, similar to Graham (2000), we examine variables that are potential determinants of a firm's non-tax demand for using debt capital, as well as its ability to bear debt. Second, we examine tax-related explanations, such as the existence of difficult-to-measure tax shields, for why a firm may appear underlevered.

The apparently underlevered firms have substantially less debt than the comparison firms. The apparently underlevered firms are also larger, significantly older, and more profitable than the comparison firms. Given these characteristics, it is not surprising that one might suppose, at least at first glance, that these firms have underutilized debt capacity, and by extension, underutilized tax benefits of debt. If our default costs model is complete and if we capture all of the firm's tax shields, firms with computed positive net benefits are simply overly conservative with respect to their debt policy and could increase firm value by increasing their use of debt.

On the other hand, there are several non-tax reasons why these firms may not be underlevered, and in fact, only appear to be underlevered. One possibility is that these firms do not have the asset composition or operating stability to support significant levels of debt. In particular, the agency costs of debt and/or the expected costs of distress might be particularly large for some firms (e.g., recall that our expected distress cost measures in Table 7 are conditional only on observed book leverage). Consistent with these explanations, the apparently underlevered firms have higher $Q$ than the comparison firms (indicating greater growth opportunities), as well as somewhat greater earnings volatility and asset return volatility, suggesting that these firms may not be able to support quite as much debt as the comparison 
firms. The apparently underlevered firms also have much larger cash holdings than the comparison firms, which combined with higher expected growth opportunities, may indicate that these firms are concerned about their ability to access the external capital markets when investing opportunities arise. At the same time, these firms have higher dividend payouts relative to the comparison firms, which is not consistent with an explanation that the apparently underlevered firms are concerned about their inability to raise external capital. Overall, our results on the non-tax characteristics of apparently underlevered firms are similar to the findings in Graham (2000), with a similar conclusion that this analysis is unlikely to fully explain why these firms appear to use debt so conservatively.

We turn now to potential tax-related reasons for the seemingly conservative debt policy of apparently underleveraged firms. Specifically, we consider the possibility that some firms have tax shields that are not easily captured by researchers' measures of taxable income (e.g., R\&D and general business tax credits, employee stock option exercises, etc.). Table 8 shows four proxies for unmeasured tax shields: 1) the difference between the accrual tax expense and cash tax paid; 2) stock option deductions; 3) percentage of assets invested overseas; and 4) technology or pharmaceutical industry representation.

We compute the variable Diff [Accrual tax rate - Cash tax rate] $\%$ as the difference between accrual tax expense and cash tax paid scaled by taxable income. We further scale the measure by the top statutory tax rate to make it comparable across time.${ }^{17}$ This difference can be viewed as an aggregate measure of non-debt tax shields stemming from timing of reversals in deferred tax differences, aggressive tax planning, and tax deductions from employee stock

\footnotetext{
${ }^{17}$ For example, if a firm had accrual tax expense of $\$ 3$ and paid $\$ 2$ in cash tax on $\$ 10$ of taxable income when the top statutory rate was $40 \%$, Diff [Accrual tax rate - Cash tax rate] $\%$ would be $((\$ 3-\$ 2) / \$ 10) / 40 \%=25 \%$. We also note that our reference to accrual tax expense is synonymous with current tax expense commonly disclosed in corporate financial statement tax footnotes.
} 
options. Specifically, firms with higher values of this variable will have less need of debt tax shields. In addition, employee stock option plans can generate tax deductions that are not detected in researchers' measurement of taxable income. These deductions do not appear in financial statements prior to 2005. As a proxy for high expected future option tax deductions, we construct an indicator variable equal to one if the firm-year is in the top quintile of option value outstanding as a percent of average assets, and zero otherwise. ${ }^{18}$ Further, because firms direct operating activities to foreign countries with comparatively low tax rates, firms with extensive foreign earnings are likely to have "true" MTRs lower than those simulated using U.S. statutory rates (see Graham 2000, p. 1924). We use the percentage of assets in foreign countries as a proxy for unremitted foreign earnings that may be shielded from higher U.S. tax rates. Finally, we create indicator variables for whether the firm is in the high tech or pharmaceutical industries. These industries are well-known to shield U.S. taxable income through investment tax credits and/or transfer pricing.

Consistent with the presence of tax shields that are not captured in taxable income, the apparently underlevered firms have a significantly larger difference between accrual tax expense and cash tax expense than the comparison firms. Further, these firms show a significantly higher value for the stock option deductions proxy, and have a higher percentage of foreign assets than the comparison firms, suggesting that the apparently underlevered firms may have difficult-tomeasure non-debt tax shields that lower the expected tax benefits these firms would receive from increasing their debt levels. Finally, we find that the apparently underlevered firms have significantly higher membership than the comparison firms in the high tech and pharmaceutical

\footnotetext{
${ }^{18}$ High option deductions is an indicator variable equal to one if the firm's Black Scholes value of its outstanding options is in the top quintile of firms for a given year. Because we only have data available on option values for certain firms (and for the years 1993 to 2003), we develop a model of expected value of employee options. Specifically, we regress the Black Scholes value of outstanding options scaled by average assets on $1 / Q$, the volatility of returns, log of average assets, and Fama and French (1997) industry dummies, and use the fitted parameters to predict high option use.
} 
industries, suggesting that these firms may have investment tax credits and other tax shields that also lower the expected tax benefit from increasing leverage. Taken as a whole, these results suggest that the apparently underlevered firms may have lower actual taxable income than a researcher's estimate of taxable income might indicate.

In untabulated results, we also separately examine apparently underlevered firms that use no debt since these firms may have different reasons for their capital structure choice than apparently underlevered firms that use at least some debt. In Table 8, there are 1,248 firms-years included in column 1 and 1,168 firm-years in column 2 that report no debt on their balance sheet. These no-debt apparently underlevered firms look very similar to the other apparently underlevered firms except that they are much smaller (median assets of $\$ 40$ million), younger (seven years old), have more cash (32\% of assets), and have a higher percentage of their assets overseas $(40 \%)$. However, like the full sample of apparently underlevered firms, the no-debt apparently underlevered firms appear to have somewhat less operating stability, as well as higher unmeasured non-debt tax shields than the comparison sample.

Overall, the results in Table 8 suggest that the apparently underlevered firms differ from comparison firms in ways that may shed light on these firms' seemingly conservative debt policy. Specifically, we find that the apparently underlevered firms may have lower taxable income (stemming from difficult-to-measure non-debt tax shields) than a researcher's estimate might indicate, as suggested by a greater proportion of foreign assets, greater stock option deductions, and greater membership in high tech or pharmaceutical industries. Further, these firms have greater growth opportunities, volatility, and cash holdings, potentially indicating somewhat lower debt capacity. 


\section{Conclusion}

In this paper, we show that prior research overestimates the magnitude of underutilized tax benefits of debt. In our investigation of the marginal tax benefit of debt, we make three contributions to the corporate tax and capital structure literatures. First, we document and describe measurement errors in the RW model used to estimate future taxable income in MTR computations. We also show that these measurement problems in estimating future taxable income have an economically significant impact on corporate MTR computations. Second, we develop an intuitive NP procedure for simulating levels of future taxable income that produces more accurate estimates of the distribution of future taxable income. Third, to explore the relevance of our approach in a corporate finance context, we re-examine prior research that claims that many corporations fail to take advantage of additional tax shield benefits and therefore appear to be underlevered. Using our approach to estimate corporate MTRs, we find lower benefits from additional interest tax shields, suggesting that many corporations are not as underlevered as previously thought. Further, we more closely examine the remaining group of firms that appear underlevered and find evidence suggesting that these firms have difficult-tomeasure non-debt tax shields that are not captured in researchers' estimates of taxable income. 


\section{Appendix A. Estimating post-financing and pre-financing taxable income}

In order to simulate the marginal tax rates, it is necessary to forecast up to 22 years of taxable income. Forecasting taxable income, either with the RW or with our NP method, requires us first to define taxable income. Unfortunately, taxable income is unobservable, so researchers have to estimate it from financial statement information. In this appendix, we describe our understanding of how Graham (2000) computes taxable income and our adjustments to his computation.

In the simulation process, two measures of taxable income before interest are estimated:

1. Taxable income before interest and before transitory items ("taxable income before transitory items"): This "cleaner" measure excludes special items, extraordinary items, and discontinued operations, and is used for estimating the distribution of future taxable income (i.e., $\hat{\mu}_{i}$ and $\hat{\sigma}_{i}$ in Eq. (1)).

2. Taxable income before interest including special items, extraordinary items, and discontinued operations ("taxable income"): This measure is the estimate of taxable income reported on the firm's tax filings. That is, income (losses) due to special items, extraordinary items, and discontinued operations is taxable (tax-deductible). We use this measure to estimate historic taxes paid and also to measure future actual taxable income. 
Graham (2000, p. 1938) defines taxable income before transitory items as:

taxable income before transitory items ${ }_{G r}=$ EBIT (operating earnings after depreciation [data178] + non-operating income [data61]) + interest on leases - timing differences estimated using deferred taxes from the cash flow statement (data126/income appropriate statutory tax rate). ${ }^{19,20}$

Graham (2000, p. 1938) estimates the second measure, taxable income after transitory items, by adding back pre-tax extraordinary items and discontinued operations to the definition of taxable income in (A2):

taxable income $_{G r}=$ taxable income before transitory items ${ }_{G r}+$ pre-tax extraordinary items and discontinued operations (data48)/(1- income appropriate statutory tax rate). ${ }^{21}$

We make three adjustments to the estimation of taxable income that we believe more correctly use financial statement data to estimate taxable income. Our first adjustment is that we use deferred tax expense reported on the income statement (data50) to estimate the timing difference between book and tax income. Graham uses deferred taxes reported on the statement of cash flows or on the balance sheet. Prior to 1993, there was significant heterogeneity in the reporting of deferred taxes on the statement of cash flows (data126). An analysis of the Compustat Industrial Annual file reveals that in over $20 \%$ of the observations that have non-zero,

\footnotetext{
${ }^{19} \mathrm{We}$ assume these are the appropriate Compustat data items, but we note that we have been unable to find any explicit explanation of the Compustat data items used.

${ }^{20}$ We assume that non-operating income (data61) is included in the definition of EBIT. The standard definition of EBIT includes operating and non-operating income before interest and taxes. However, GLS (1998, p. 143) states that they begin with "the firm's operating income after depreciation...but before interest expenses are deducted" which doesn't appear to include non-operating activities. We also assume that an adjustment is made for timing differences although Graham (2000, p. 1938) does not explicitly state that this is the case. Finally, Graham (1996b, footnote 3) notes that when (data126) is missing, the change in the balance sheet (data35/74) deferred taxes is used to estimate timing differences.

${ }^{21}$ Note that in Graham (1996b), an adjustment is also made for the minority interest (data49). However, since the starting point in later work is assumed to be EBIT, the minority interest is already included.
} 
non-missing deferred tax expense (data50), deferred taxes from the statement of cash flows are zero, missing, or combined with other items. In addition, deferred taxes from the statement of cash flows may include taxes associated with extraordinary items or discontinued operations and/or the change in current income taxes payable, therefore, leading to duplicate adjustment for some taxes. ${ }^{22}$ Compustat-reported balance sheet deferred taxes are also flawed. Compustat only records the long-term deferred tax liability reported on a firm's balance sheet in data35/74. ${ }^{23}$ Since deferred tax expense reports the change in the firm's cumulative deferred tax position, it provides a better estimate of the periods' timing differences.

Our second adjustment is that we return to Shevlin's (1990) methodology of estimating current year timing differences by using the top statutory tax rate to gross up deferred taxes to a pre-tax basis. Deferred taxes are reported in the financial statements using the anticipated future statutory tax rate. Since the U.S. corporate income tax rates reach the top statutory tax rates at relatively low levels of income (currently $\$ 10$ million), firms rarely record deferred taxes at less than the top statutory tax rate.

Finally, we incorporate special items into our estimate of historical taxable income. However, like extraordinary/discontinued operations, special items are not considered in our estimates of the drift and volatility of future income.

These three changes lead to our revised estimates of taxable income before transitory items $_{N P}$ and taxable income ${ }_{N P}$ that correspond to (A1) and (A2) above:

\footnotetext{
${ }^{22}$ Taxes associated with extraordinary items and discontinued operations are intentionally omitted from deferred tax expense (data50).

${ }^{23}$ As an example of an error, consider the deferred tax assets and liabilities disclosed in IBM's 2005 financial statements. The tax footnote reports that overall IBM has a $\$ 1.554$ billion net deferred tax asset (which is the correct number that should be used in computing timing differences). However, Compustat data35/74, Deferred Taxes and Investment Tax Credit, reports a $\$ 1.879$ billion liability. The $\$ 1.879$ billion reported by Compustat is actually the long-term component of the deferred tax liability. Compustat reports the wrong number because it fails to subtract off the $\$ 1.765$ in current deferred tax assets and the $\$ 1.832$ in long-term deferred assets (which computation would lead to the correct $\$ 1.554$ billion net deferred tax asset).
} 
taxable income before transitory items $\mathrm{s}_{N P}=\mathrm{EBIT}+$ interest on leases - timing differences estimated using deferred tax expense reported on the income statement (data50/maximum statutory tax rate),

${\text { taxable } \text { income }_{N P}=\text { taxable income before transitory items }}_{N P}+$ pre-tax extraordinary items and discontinued operations (data48)/(1- maximum statutory tax rate) + special items (data17). 


\section{Appendix B. The kink calculation}

We follow Graham (2000, p. 1915) and van Binsbergen, Graham, and Yang (2007, footnote 5) and define the "kink" as the first interest increment at which the firm has a decline in its marginal tax rate of at least 50 basis points. ${ }^{24}$ The intuition of estimating the kink is straightforward: MTRs are estimated by deducting various increments of interest expense from taxable income, and the kink is the increment of interest expense immediately before that increment of interest expense which results in the computed MTR dropping by at least 50 basis points. We follow Graham and add the following increments to before-financing taxable income: $0 \% ; 20 \% ; 40 \% ; 60 \% ; 80 \% ; 100 \% ; 120 \% ; 160 \% ; 200 \% ; 300 \% ; 400 \% ; 500 \% ; 600 \% ; 700 \%$; and $800 \%$.

Although the kink computation is intuitive, it is important to describe the estimation of the interest deductions at each increment. Note that we not only have to address how to simulate future interest deductions, but that we also have to consider how to adjust past interest deductions. We follow Graham (2000, p. 1906), and simulate future interest expense based on changes in the interest coverage ratio. So long as income at $t$ is positive, future interest is changed by the ratio of income at $t$ to income at $t$ - 1 . If income at $t$ is negative, we follow Graham and hold interest constant for that year (i.e., interest at time $t=$ interest at time $t$-1).

In terms of past interest deductions, we infer from Graham (2000, p. 1905) that, for the purposes of computing the MTR, interest expense in historical taxable income is retroactively adjusted. For example, when estimating the MTR at the 50\% interest deduction increment at time $t$, we assume that interest deductions in periods $t$ - $n$ to $t$ - 1 are set to $50 \%$ of actual.

\footnotetext{
${ }^{24}$ As noted above, another economically meaningful interpretation of kink is the first increment at which the firm has a post-financing marginal tax rate that is at least 50 basis points lower than the top statutory tax rate. All of our inferences hold using this kink definition.
} 
Although we adjust historical taxable income at each interest increment, we do not adjust the underlying distribution of taxable income from which we estimate future taxable income. We believe that this is most comparable to the kink generated in Graham (2000) where it appears that Graham simulates future income using the income distribution for pre-financing taxable income. In other words, the $\hat{\mu}_{i}$ and $\hat{\sigma}_{i}$ in Eq. (1) are estimates of the mean and standard deviation of changes in past pre-financing taxable income before transitory items. (Taxable income before transitory items is defined in Eq. (A1') in Appendix A.) In order to estimate the kink at each interest increment, the additional interest expense is subtracted from the future taxable income simulated using Eq. (1). Similarly, our NP method continues to draw future income from prefinancing ROA bins corresponding to the path of simulated pre-financing income. Doing this means that we assume that the addition of debt does not change the firm's future pre-financing cash flows. Said another way, neither our method nor Graham's allows interest deductions to alter the volatility of future income.

Finally, unlike Graham (2000), we do not incorporate state income taxes into our estimate of kink. ${ }^{25}$ Graham incorporates state income taxes by adding $(1-\mathrm{MTR}) *$ state tax rate in the firm's headquarters to the federal MTR. However, each state has its own graduated rate structure, definition of taxable income, net operating losses, credits etc. that should be incorporated into the MTR computation. In addition, some assumption must be made regarding the apportionment of income across states. Note that ignoring state taxes potentially increases our estimates of kink (consider that the larger the applicable tax rate, the larger the change in the present value of the tax savings from moving a dollar deduction one more period into the future).

\footnotetext{
${ }^{25}$ Graham does not incorporate state taxes into his marginal tax rates provided on his website.
} 


\section{Appendix C. Calculation of expected distress costs}

We measure the expected costs of increased leverage following the mapping between book leverage and expected distress costs developed by Molina (2005) and Almeida and Philippon (2007). This mapping is computed in two steps. In the first step, a firm's leverage ratio is mapped into a credit rating, and then in the second step, the credit rating is mapped into an expected cost of distress. To infer a firm's credit rating, we use the mapping between bond ratings and predicted book leverage ratios presented in Almeida and Philippon's Table V in the column headed “Molina (2005) Regression Model." For example, a firm with an 'A' ('B') credit rating has predicted book leverage of $28 \%(57 \%)$. We interpolate distress costs for book leverage ratios between the predicted values for a given credit rating, for example, between $3 \%$ (AAA) and 16\% (AA). To map credit ratings into distress costs, we use the expected risk-adjusted costs of distress reported in the second column of Almeida and Philippon's Table IV, Panel B. We follow Almeida and Philippon's benchmark assumption that default costs are $16.5 \%$ of firm value, which is the midpoint of Andrade and Kaplan's (1998) estimates of loss in firm value given distress of $10 \%$ to $23 \%$. For example, a firm with an 'A' ('B') credit rating has a riskadjusted cost of financial distress of 3.83\% (9.54\%). Thus, in our analysis, we map book leverage of $28 \%(57 \%)$ into risk-adjusted costs of financial distress of $3.83 \%(9.54 \%)$. A limitation of this analysis is that distress costs vary for many reasons besides book leverage. However, the advantage of this approach is that we are able to tie our analysis to the costs of increased leverage estimated by prior researchers in this area, and concentrate on our novel contribution, which is better measurement of the tax benefits of increased leverage. 


\section{References}

Almeida, H., Philippon, T., 2007. The risk-adjusted cost of financial distress. Journal of Finance $62,2557-2586$.

Andrade, G., Kaplan, S., 1998. How costly is financial (not economic) distress? Evidence from highly leveraged transactions that became distressed. Journal of Finance 53, 1443-1493.

van Binsbergen, J., Graham, J., Yang, J., 2007. The cost of debt. Unpublished working paper. Duke University.

Barber, B., Lyon, J., 1996. Detecting abnormal operating performance: The empirical power and specification of test statistics. Journal of Financial Economics 41, 3: 359-399.

Brooks, L., Buckmaster, D., 1976. Further evidence of the time series properties of accounting income. Journal of Finance 31, 1359-1373.

Brown, L., 1993. Earnings forecasting research: Its implications for capital markets research. International Journal of Forecasting 9, 295-340.

Campbell, J., Hilscher, J., Szilagyi, J., 2008. In search of distress risk. Journal of Finance 63, 2899-2939.

Dechow, P., Sloan, R., 1997. Returns to contrarian investment strategies: Tests of naive expectations hypotheses. Journal of Financial Economics 43, 3-27.

Fama, E., French, K., 1997. Industry costs of equity. Journal of Financial Economics $43,153-193$.

Fama, E., MacBeth, J., 1973. Risk, return and equilibrium: Empirical Tests. Journal of Political Economy 81, 607-636.

Graham, J., 1996a. Debt and the marginal tax rate. Journal of Financial Economics 41, 41-73. 
Graham, J., 1996b. Proxies for the corporate marginal tax rate. Journal of Financial Economics $42,187-221$.

Graham, J., 2000. How big are the tax benefits of debt? Journal of Finance 55, 1901-1941

Graham, J., Kim, H., 2009. Simulating taxable income and corporate marginal income tax rates. Unpublished working paper. Duke University.

Graham, J., Lemmon, M. Schallheim, J., 1998. Debt, leases, taxes and the endogeneity of corporate tax status. Journal of Finance 53, 131-162.

Hayn, C., 1995. The information content of losses. Journal of Accounting and Economics 20, $125-153$.

Molina, C., 2005. Are firms underleveraged? An examination of the effect of leverage on default probabilities. Journal of Finance 60, 1427-59.

Oler, M., Shevlin, T., Wilson, R., 2007. Examining investor expectations concerning tax Savings on the repatriations of foreign earnings under the American Jobs Creation Act of 2004. Journal of the American Taxation Association 29, 25-55.

Rosenbaum, P., Rubin, D., 1983. The central role of the propensity score in observational studies for causal effects. Biometrika 70, 41-55.

Shevlin, T., 1990. Estimating corporate marginal tax rates with asymmetric tax treatment of gains and losses. The Journal of the American Taxation Association 12, 51-67. 
Table 1

Descriptive statistics

This table presents descriptive statistics for Taxable income before transitory items for our 1980-2007 sample of 140,146 observations with data available to compute one-year-ahead taxable income. We scale all variables in this table by average total assets $t\left(\operatorname{Ave}\left(\mathrm{TA}_{t}\right)\right)$. Each value shown is computed by first computing that variable's median for each year (from 1980 to 2007), and then taking the average of the median values. Taxable income before transitory items is taxable income before interest expense, special items, extraordinary items, and discontinued operations. Taxable income is taxable income before interest expense including special items,

extraordinary items, and discontinued operations. $\mu_{t}$ is the mean change in taxable income before transitory items for all available data up to and including year $t$. $\sigma_{t}$ is the standard deviation of the change in taxable income before transitory items for all available data up to and including year $t$. Income groups are formed by partitioning the negative (positive) income subsamples into two (four) equal-sized groups by ranking on taxable income before transitory items at year $t-2$ scaled by average total assets at year $t-2$. These cut-offs are used to partition taxable income before transitory items at year $t$ scaled by average total assets at year $t$.

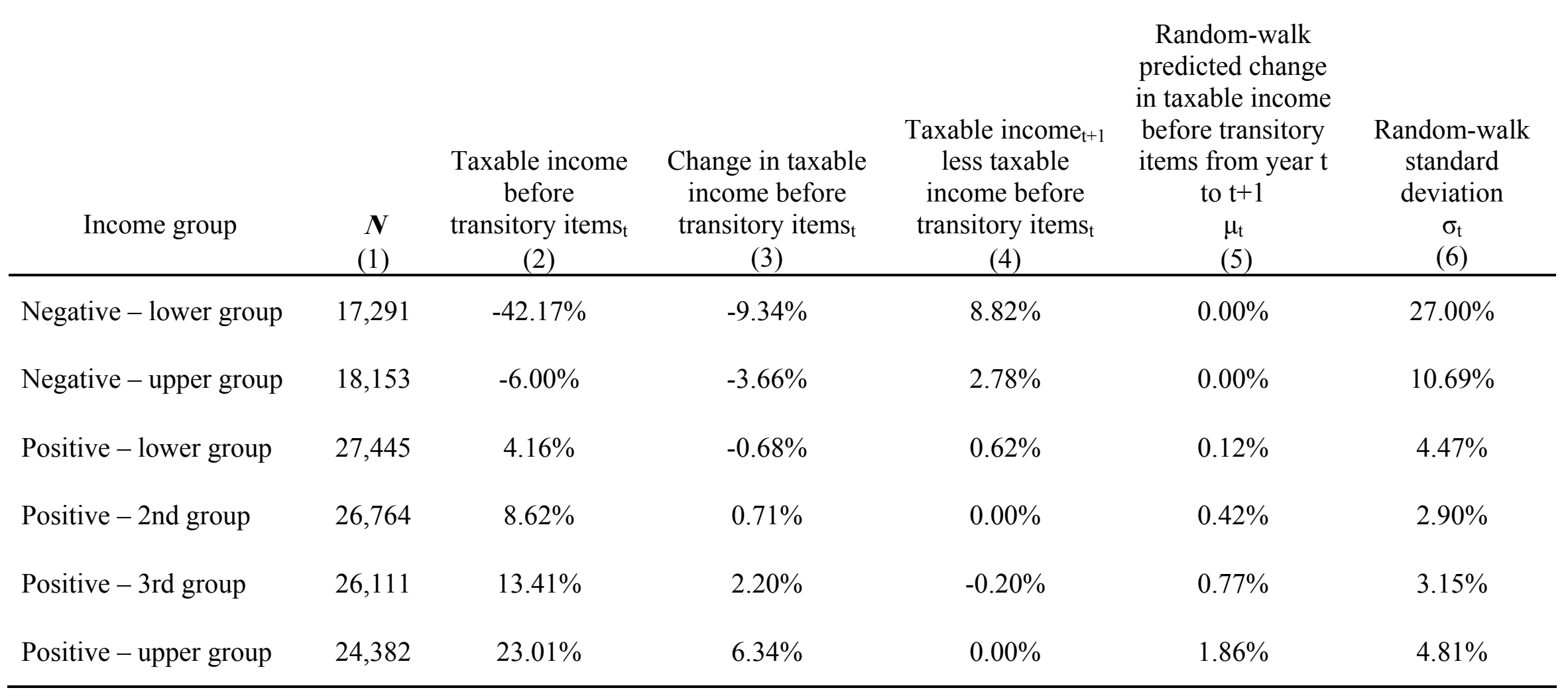


Table 2

Ability of RW and NP income simulations to capture the distribution of five-year-ahead taxable income

This table examines the ability of the RW and NP income simulations to capture the distribution of five-year-ahead taxable income using the 1980-2002 sample of firms with five-year-ahead taxable income available. If the simulation is successful, then approximately $5 \%$ of actual five-year-ahead taxable income realizations will be less than the $5^{\text {th }}$ percentile of the simulated distribution, etc. The simulated distribution of the random-walk taxable income $t_{t+5}$ is created by drawing from Graham's (1996b) RW assumption. The simulated distribution of the non-parametric taxable income $t_{t+5}$ is created by drawing from six-by-five annual ROA/average total assets sort. One hundred draws per firm from each of these distributions are used to generate the percentiles shown below. Then, actual taxable income $t_{t+5}$ is compared with these drawn distributions. The panels show proportions of taxable income $e_{t+5}$ that fall in designated percentiles. Forecast error is actual taxable income $t_{t+5}$ less simulated taxable income $t_{+5}$ scaled by average total assets. Each value shown in the table is computed by first computing that variable's value for each year (from 1980 to 2002), and then taking the average of the values. Income groups are formed by partitioning the negative (positive) income subsamples into two (four) equal-sized groups by ranking on ROA at year $t$-2 (i.e., Taxable income before transitory items $t_{t-2} /$ Average total assets $t_{t-2}$ ). These cut-offs are used to partition ROA at year $t$ (i.e., Taxable income before transitory items $/$ /Average total assets $t$ ).

\begin{tabular}{|c|c|c|c|c|c|c|}
\hline Forecasting method & $N$ & $\begin{array}{c}\text { Median forecast } \\
\text { error }\end{array}$ & $\begin{array}{l}\%<5^{\text {th }} \text { pctile } \\
\text { (should be } 5 \% \text { ) }\end{array}$ & $\begin{array}{l}\% \text { in } 25^{\text {th }} \text { to } 75^{\text {th }} \text { pctile } \\
\text { (should be } 50 \% \text { ) }\end{array}$ & $\begin{array}{l}\%>95^{\text {th }} \text { pctile } \\
\text { (should be } 5 \% \text { ) }\end{array}$ & $\begin{array}{c}\text { Estimated } \\
\text { Sim. SD/Actual SD } \\
\end{array}$ \\
\hline
\end{tabular}

$(5)$

Panel A: Full sample of firm-years from 1980 to 2002

\begin{tabular}{lccccc}
\hline Random-walk & 88,729 & $-0.13 \%$ & $19.86 \%^{\mathrm{a}}$ & $34.91 \%^{\mathrm{a}}$ & $18.84 \%^{\mathrm{a}}$ \\
\hline Non-parametric & 88,729 & $-1.70 \%$ & $5.20 \%$ & $53.85 \%^{\mathrm{a}}$ & $5.21 \%$
\end{tabular}

Panel B: Low-income sample of firm-years in lower half of negative ROA subsample from 1980 to 2002

\begin{tabular}{llllll}
\hline Random-walk & 9,349 & $19.28 \%^{\mathrm{a}}$ & $13.46 \%^{\mathrm{a}}$ & $39.10 \%^{\mathrm{a}}$ & $17.87 \%^{\mathrm{a}}$ \\
\hline Non-parametric & 9,349 & $-10.06 \%^{\mathrm{a}}$ & $7.71 \%^{\mathrm{a}}$ & $53.45 \%$ & $4.16 \%$
\end{tabular}

Panel C: High-income sample of firm-years in upper quartile of positive ROA subsample from 1980 to 2002

\begin{tabular}{|c|c|c|c|c|c|c|}
\hline Random-walk & 16,848 & $-9.41 \%{ }^{\mathrm{a}}$ & $34.71 \%{ }^{\mathrm{a}}$ & $20.94 \%{ }^{\mathrm{a}}$ & $20.18 \%{ }^{\mathrm{a}}$ & $37.34 \%{ }^{\mathrm{a}}$ \\
\hline
\end{tabular}

${ }^{a}$ Significantly different from its value under the null at $p<0.05$ level (based on Fama-MacBeth standard errors).

${ }^{b}$ We estimate the ratio of the simulated standard deviation to the actual standard deviation as: $\left(\Phi^{-1}(1-\%>95\right.$ th percentile $)-\Phi^{-1}(\%<5$ th percentile) $) /\left(2 * \Phi^{-1}(.95)\right)$, where $\Phi^{-1}(\cdot)$ is the inverse of the standard normal. $\%<5$ th percentile and $\%>95$ th percentile are as shown in the table. This approximation is exact if both actual and simulated income are normally distributed. 
Table 3

MTR summary statistics and correlations:

NP_MTR is the pre-financing marginal tax rate estimated using the non-parametric method. RW_MTR is the replication of Graham's pre-financing marginal tax rates using the RW simulation as described in Graham, Lemmon, and Schallheim (1998). WEB_MTR is the pre-financing marginal tax rates provided on http://faculty.fuqua.duke.edu/ jgraham/website/. The sample is from 1980-2007.

Panel A: Comparison of the NP rate (NP ), our replication of Graham's rate ( $\left.R W_{\perp}\right)$, and Graham's rate (WEB_)

Raw MTRs

\begin{tabular}{|c|c|c|c|c|}
\hline Rate & & $\begin{array}{l}\mathrm{NP} \\
\mathrm{MTR}\end{array}$ & $\begin{array}{l}\text { RW- } \\
\text { MTR }\end{array}$ & $\begin{array}{l}\text { WEB_ } \\
\text { MTR }\end{array}$ \\
\hline$N$ & & 157,513 & 157,513 & 125,669 \\
\hline Mean & & $29 \%$ & $28 \%$ & $29 \%$ \\
\hline Std dev & & $12 \%$ & $14 \%$ & $15 \%$ \\
\hline $0 \%$ & Min & $0 \%$ & $0 \%$ & $0 \%$ \\
\hline $1 \%$ & & $2 \%$ & $0 \%$ & $0 \%$ \\
\hline $5 \%$ & & $6 \%$ & $1 \%$ & $1 \%$ \\
\hline $10 \%$ & & $9 \%$ & $4 \%$ & $3 \%$ \\
\hline $25 \%$ & Q1 & $19 \%$ & $17 \%$ & $18 \%$ \\
\hline $50 \%$ & Median & $33 \%$ & $34 \%$ & $34 \%$ \\
\hline $75 \%$ & Q3 & $35 \%$ & $35 \%$ & $36 \%$ \\
\hline $90 \%$ & & $45 \%$ & $46 \%$ & $46 \%$ \\
\hline $95 \%$ & & $46 \%$ & $46 \%$ & $46 \%$ \\
\hline $99 \%$ & & $46 \%$ & $46 \%$ & $46 \%$ \\
\hline $100 \%$ & Max & $51 \%$ & $51 \%$ & $51 \%$ \\
\hline
\end{tabular}


Table 3 (continued)

Summary statistics and correlations:

Panel B: Comparison of the NP rate (NP ), our replication of Graham's rate ( $R W$ ), and Graham's rate (WEB_)

MTRs as a $\%$ of top statutory rate

\begin{tabular}{ccccc}
\hline & & $\mathrm{NP}$ & $\mathrm{RW}$ & $\mathrm{WEB}$ \\
Rate & & $\mathrm{MTR}$ & $\mathrm{MTR}$ & $\mathrm{MTR}$ \\
\hline$N$ & & 157,513 & 157,513 & 125,669 \\
Mean & & $76 \%$ & $75 \%$ & $75 \%$ \\
Std dev & & $30 \%$ & $35 \%$ & $36 \%$ \\
& & & & \\
$0 \%$ & Min & $0 \%$ & $0 \%$ & $0 \%$ \\
$1 \%$ & & $7 \%$ & $0 \%$ & $0 \%$ \\
$5 \%$ & & $17 \%$ & $3 \%$ & $2 \%$ \\
$10 \%$ & & $26 \%$ & $12 \%$ & $8 \%$ \\
$25 \%$ & $\mathrm{Q} 1$ & $52 \%$ & $47 \%$ & $48 \%$ \\
$50 \%$ & Median & $93 \%$ & $97 \%$ & $98 \%$ \\
$75 \%$ & $\mathrm{Q} 3$ & $99 \%$ & $100 \%$ & $100 \%$ \\
$90 \%$ & & $100 \%$ & $100 \%$ & $100 \%$ \\
$95 \%$ & & $100 \%$ & $100 \%$ & $101 \%$ \\
$99 \%$ & & $106 \%$ & $109 \%$ & $109 \%$ \\
$100 \%$ & Max & $150 \%$ & $150 \%$ & $127 \%$ \\
\hline$\%$ Less than & & & & $62 \%$ \\
\hline statutory rate & & $85 \%$ & $59 \%$ & \\
\hline
\end{tabular}




\section{Table 4}

Distribution of MTRs by income

Values shown in the table are sample averages for 1980-2007. Income groups are formed by partitioning the negative (positive) income subsamples into two (four) equal-sized groups by ranking on ROA at year $t$-2 (i.e., taxable income before transitory items $s_{t-2} /$ Ave $\left(\mathrm{TA}_{t-2}\right)$ ). These cut-offs are used to partition ROA at year $t$ (i.e., taxable income before transitory items $/$ /Ave $\left(\mathrm{TA}_{t}\right)$ ). NP_MTR is the pre-financing MTR estimated using the non-parametric method. RW_MTR is the replication of Graham's pre-financing MTRs as described in Graham, Lemmon, and Schallheim (1998). WEB MTR is the pre-financing MTRs provided on http://faculty.fuqua.duke.edu/ jgraham/website/. The Web site-provided (WEB MTR) tax rates have fewer observations. By bin, there are 14,069, 15,241, 25,600, $24,297,24,496$, and 21,966 observations. ${ }^{*}, * * * *$ Represent significance at the $5 \%, 1 \%$, and $0.1 \%$ levels, respectively. Tests of differences use Fama-MacBeth standard errors.

\begin{tabular}{|c|c|c|c|c|c|c|c|}
\hline $\begin{array}{l}\text { Income group: } \\
\text { taxable income before } \\
\text { transitory items/assets }\end{array}$ & $N$ & $\begin{array}{l}\mathrm{NP} \\
\mathrm{MTR}\end{array}$ & Difference & $\begin{array}{l}\mathrm{RW}_{-} \\
\mathrm{MTR}\end{array}$ & Difference & $\begin{array}{l}\text { WEB } \\
\text { MTR }\end{array}$ & $\begin{array}{l}\text { Difference: } \\
\text { NP_MTR - } \\
\text { WEB_MTR }\end{array}$ \\
\hline Negative - lower $50 \%$ & 20,804 & $10.8 \%$ & $5.0 \% 0^{* * *}$ & $5.8 \%$ & $0.0 \%$ & $6.1 \%$ & $5.0 \% 0^{* * *}$ \\
\hline Negative - upper $50 \%$ & 21,315 & $20.2 \%$ & $4.1 \% 0^{* * *}$ & $16.1 \%$ & $0.6 \%$ & $17.0 \%$ & $4.8 \% 0^{* * *}$ \\
\hline Positive - lower $25 \%$ & 30,453 & $31.2 \%$ & $0.5 \%$ ** & $30.7 \%$ & $1.7 \% \%^{* * *}$ & $29.7 \%$ & $2.2 \%{ }^{* * *}$ \\
\hline Positive - 2nd 25\% & 29,484 & $34.6 \%$ & $-1.0 \% 0^{* * *}$ & $35.6 \%$ & $1.1 \%{ }^{* * *}$ & $34.9 \%$ & $0.2 \%$ \\
\hline Positive - upper $25 \%$ & 26,694 & $34.3 \%$ & $-1.8 \%$ *** & $36.1 \%$ & $0.9 \% 0^{* * *}$ & $35.8 \%$ & $-0.7 \% 0^{* * *}$ \\
\hline
\end{tabular}


Table 5

Summary statistics on kink: Graham (2000), RW, and NP kinks

Kink is defined as the first interest increment at which the firm has a decline in its marginal tax rate of at least 50 basis points. Graham 2000 kinks are from Table II from Graham (2000). RW kink is our replication of Graham 2000. Kinks are calculated by estimating the marginal benefit curve by plotting the marginal tax rates determined by adding $20 \%$ to $800 \%$ of actual interest expense (interest expense plus one-third of rent expense) to pre-financing taxable income.

\begin{tabular}{|c|c|c|c|c|c|c|}
\hline Panel A: $1980-1994$ & \multicolumn{2}{|c|}{ Graham 2000} & \multicolumn{2}{|c|}{$R W$ kink } & \multicolumn{2}{|c|}{ NP kink } \\
\hline Kink & $N$ & Average kink & $N$ & Average kink & $N$ & Average kink \\
\hline Average & 87,643 & 2.36 & 79,400 & 1.87 & 79,400 & 0.98 \\
\hline Distribution: & $N$ & $\%$ & $N$ & $\%$ & $N$ & $\%$ \\
\hline Kink $<1$ & 37,173 & $42 \%$ & 40,451 & $51 \%$ & 56,520 & $71 \%$ \\
\hline $1 \leq \operatorname{Kink}<2$ & 11,969 & $14 \%$ & 8,852 & $15 \%$ & 10,497 & $13 \%$ \\
\hline Kink $=2$ & 9,496 & $11 \%$ & 7,490 & $9 \%$ & 4,355 & $5 \%$ \\
\hline Kink $=3$ & 6,580 & $7 \%$ & 4,621 & $6 \%$ & 2,023 & $3 \%$ \\
\hline Kink $\geq 4$ & 22,425 & $26 \%$ & 14,985 & $19 \%$ & 6,005 & $8 \%$ \\
\hline Total & 87,643 & $100 \%$ & 79,400 & $100 \%$ & 79,400 & $100 \%$ \\
\hline Total $<1$ & 37,173 & $42 \%$ & 40,451 & $51 \%$ & 56,250 & $71 \%$ \\
\hline Total $>=1$ & 50,470 & $58 \%$ & 38,839 & $49 \%$ & 22,880 & $29 \%$ \\
\hline
\end{tabular}




\begin{tabular}{|c|c|c|c|c|c|c|}
\hline \multirow{2}{*}{$\frac{\text { Panel B: } 1980-2007}{\text { Kink }}$} & \multicolumn{2}{|c|}{ Graham 2000} & \multicolumn{2}{|c|}{$R W$ kink } & \multicolumn{2}{|c|}{ NP kink } \\
\hline & $N$ & Average kink & $N$ & Average kink & $N$ & Average kink \\
\hline Average & 87,643 & 2.36 & 157,513 & 1.74 & 157,513 & 1.06 \\
\hline Distribution: & $N$ & $\%$ & $N$ & $\%$ & $N$ & $\%$ \\
\hline Kink $<1$ & 37,173 & $42 \%$ & 87,697 & $56 \%$ & 109,232 & $69 \%$ \\
\hline $1 \leq \operatorname{Kink}<2$ & 11,969 & $14 \%$ & 20,618 & $13 \%$ & 20,457 & $13 \%$ \\
\hline Kink $=2$ & 9,496 & $11 \%$ & 13,019 & $8 \%$ & 9,554 & $6 \%$ \\
\hline Kink $=3$ & 6,580 & $7 \%$ & 8,306 & $5 \%$ & 4,615 & $3 \%$ \\
\hline Kink $\geq 4$ & 22,425 & $26 \%$ & 27,873 & $18 \%$ & 13,655 & $9 \%$ \\
\hline Total & 87,643 & $100 \%$ & 157,513 & $100 \%$ & 157,513 & $100 \%$ \\
\hline Total $<1$ & 37,173 & $42 \%$ & 87,697 & $56 \%$ & 109,232 & $69 \%$ \\
\hline Total $>=1$ & 50,470 & $58 \%$ & 69,816 & $44 \%$ & 48,281 & $31 \%$ \\
\hline
\end{tabular}


Table 6

Comparison of RW kink vs. NP kink by income group

Values shown in the table are sample averages from 1980-2007. Kink calculated as described in Table 5. Income groups are formed by partitioning the negative (positive) income subsamples into two (four) equal-sized groups by ranking on ROA at year $t-2$ (i.e., taxable income before transitory items $t_{t-2} / \mathrm{Ave}\left(\mathrm{TA} \mathrm{A}_{t-2}\right)$ ). These cutoffs are used to partition ROA at year $t$ (i.e., taxable income before transitory items $/$ Ave(Assets $t)$ ). ${ }^{*}, * * * * *$ Represent significance at the $5 \%, 1 \%$, and $0.1 \%$ levels, respectively. Tests of differences use Fama-MacBeth standard errors.

\begin{tabular}{|c|c|c|c|c|c|c|}
\hline Income group & $N$ & $\begin{array}{c}\text { RW } \\
\text { kink } \\
(1) \\
\end{array}$ & $\begin{array}{c}\text { NP } \\
\text { kink } \\
(2) \\
\end{array}$ & $\begin{array}{c}\mathrm{RW}-\mathrm{NP} \\
\text { kink } \\
(3)\end{array}$ & $\begin{array}{c}\text { Kink: } \\
\text { RW } \\
\text { income }^{26} \\
\text { forecast }^{26} \\
(4)\end{array}$ & $\begin{array}{c}\text { Kink: } \\
\text { Perfect } \\
\text { foresight } \\
\text { income } \\
\text { forecast }^{27} \\
(5)\end{array}$ \\
\hline Negative - lower $50 \%$ & 20,804 & 0.25 & 0.13 & $0.12 * * *$ & 0.00 & 0.00 \\
\hline Negative - upper 50\% & 21,315 & 0.79 & 0.47 & $0.32 * * *$ & 0.00 & 0.20 \\
\hline Positive - lower $25 \%$ & 30,453 & 0.60 & 0.57 & -0.03 & 0.00 & 0.00 \\
\hline Positive - 2nd 25\% & 29,484 & 1.47 & 0.88 & 0.59 *** & 2.00 & 0.00 \\
\hline Positive - 3rd 25\% & 28,763 & 2.67 & 1.49 & $1.18^{* * *}$ & 3.00 & 1.60 \\
\hline Positive - upper $25 \%$ & 26,694 & 4.25 & 2.54 & $1.71 * * *$ & 7.00 & 2.00 \\
\hline
\end{tabular}

${ }^{26}$ GR kink calculated using the income forecast for the "typical" firm in each income group, where the median $\mathrm{ROA}_{t}, \mu_{t}$, and $\sigma_{t}$ are calculated as the average of the annual median values.

${ }^{27}$ GR kink calculated using the income forecast for the "typical" firm in each income group, where the median $\mathrm{ROA}_{t}, \mu_{t}$, and $\sigma_{t}$ are calculated as the average of the annual median values and where $\mu_{t}$ and $\sigma_{t}$ are corrected for the errors summarized in Table 2 . 
Table 7

Proxies for incremental benefits and incremental costs of extra debt

The increase in MVA from increasing interest expense to kink is estimated using Eq. (2) in Graham (2000) that expresses the tax benefit of debt net of the "personal

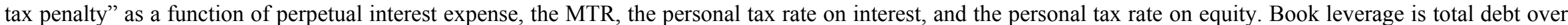

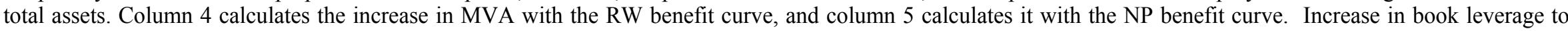

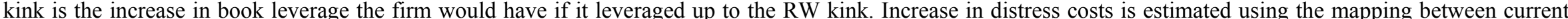

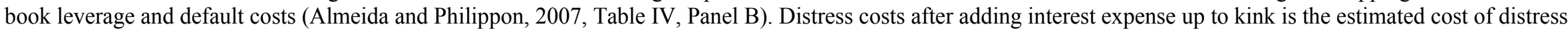

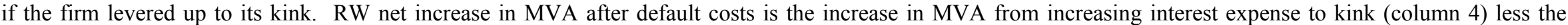

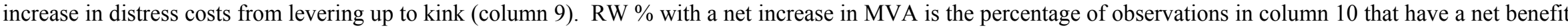

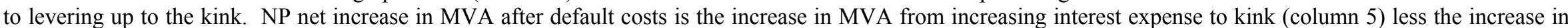

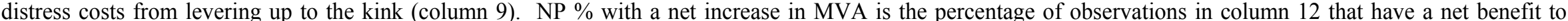
levering up to the kink. The sample covers 1980-2007.

Panel A:RW kinks

Increase in MVA from increasing

interest expense to kink:

$\underline{\text { RW net increase: }}$

Net

\begin{tabular}{|c|c|c|c|c|c|c|c|c|c|c|c|c|}
\hline $\begin{array}{l}\text { RW kink } \\
\text { group } \\
(1)\end{array}$ & $\begin{array}{c}N \\
(2)\end{array}$ & $\begin{array}{c}\% \text { of } \\
138,976 \\
N \text { Total } \\
(3)\end{array}$ & $\begin{array}{c}\text { RW } \\
\text { benefit } \\
\text { curve } \\
(4)\end{array}$ & $\begin{array}{c}\text { NP } \\
\text { benefit } \\
\text { curve } \\
(5)\end{array}$ & $\begin{array}{c}\text { NP } \\
\text { benefit/ } \\
\text { RW } \\
\text { benefit } \\
(6)\end{array}$ & $\begin{array}{c}\text { Book } \\
\text { leverage } \\
(7)\end{array}$ & $\begin{array}{l}\text { Increase } \\
\text { in book } \\
\text { leverage } \\
\text { to kink } \\
(8)\end{array}$ & $\begin{array}{l}\text { Increase } \\
\text { in distress } \\
\text { cost to } \\
\text { kink } \\
(9)\end{array}$ & $\begin{array}{c}\text { increase } \\
\text { in MVA } \\
\text { after } \\
\text { distress } \\
\text { costs } \\
(10)\end{array}$ & $\begin{array}{l}\% \text { with a } \\
\text { net } \\
\text { increase } \\
\text { in MVA } \\
(11)\end{array}$ & $\begin{array}{l}\text { increase } \\
\text { in MVA } \\
\text { after } \\
\text { distress } \\
\text { costs } \\
(12)\end{array}$ & $\begin{array}{c}\% \text { with a } \\
\text { net } \\
\text { increase } \\
\text { in MVA } \\
(13)\end{array}$ \\
\hline Kink $<1$ & 77,112 & $55.5 \%$ & $\mathrm{~N} / \mathrm{A}$ & $\mathrm{N} / \mathrm{A}$ & $\mathrm{N} / \mathrm{A}$ & $37.1 \%$ & $\mathrm{~N} / \mathrm{A}$ & $\mathrm{N} / \mathrm{A}$ & $\mathrm{N} / \mathrm{A}$ & $\mathrm{N} / \mathrm{A}$ & $\mathrm{N} / \mathrm{A}$ & $\mathrm{N} / \mathrm{A}$ \\
\hline $1 \leq \operatorname{Kink}<2$ & 17,345 & $12.5 \%$ & $1.6 \%$ & $0.7 \%$ & $43.9 \%$ & $32.8 \%$ & $11.7 \%$ & $1.4 \%$ & $0.2 \%$ & $33.7 \%$ & $-0.7 \%$ & $20.3 \%$ \\
\hline Kink $=2$ & 11,158 & $8.0 \%$ & $4.2 \%$ & $2.3 \%$ & $53.8 \%$ & $26.9 \%$ & $33.6 \%$ & $3.8 \%$ & $0.4 \%$ & $47.0 \%$ & $-1.5 \%$ & $28.8 \%$ \\
\hline Kink $=3$ & 7,195 & $5.2 \%$ & $6.3 \%$ & $3.0 \%$ & $47.4 \%$ & $22.4 \%$ & $56.8 \%$ & $5.2 \%$ & $1.1 \%$ & $51.4 \%$ & $-2.2 \%$ & $29.2 \%$ \\
\hline Kink $\geq 4$ & 26,166 & $18.8 \%$ & $5.6 \%$ & $2.0 \%$ & $35.7 \%$ & $14.4 \%$ & $84.6 \%$ & $5.8 \%$ & $-0.2 \%$ & $36.4 \%$ & $-3.8 \%$ & $18.5 \%$ \\
\hline
\end{tabular}




\begin{tabular}{|c|c|c|c|c|c|c|c|c|}
\hline $\begin{array}{l}\text { NP kink } \\
\text { group } \\
\text { (1) }\end{array}$ & $\begin{array}{c}N \\
(2)\end{array}$ & $\begin{array}{c}\% \text { of } \\
138,976 \\
N \text { Total } \\
(3)\end{array}$ & $\begin{array}{l}\text { Increase in } \\
\text { MVA } \\
\text { from } \\
\text { increasing } \\
\text { interest } \\
\text { expense to } \\
\text { kink } \\
\text { (4) }\end{array}$ & $\begin{array}{c}\text { Book } \\
\text { leverage } \\
(5)\end{array}$ & $\begin{array}{c}\text { Increase } \\
\text { in book } \\
\text { leverage } \\
\text { to kink } \\
(8)\end{array}$ & $\begin{array}{l}\text { Increase } \\
\text { in distress } \\
\text { cost to } \\
\text { kink } \\
\text { (9) }\end{array}$ & $\begin{array}{c}\text { Net } \\
\text { increase in } \\
\text { MVA } \\
\text { after } \\
\text { default } \\
\text { costs } \\
(12)\end{array}$ & $\begin{array}{l}\% \text { with a } \\
\text { net } \\
\text { increase in } \\
\text { MVA } \\
\text { (13) }\end{array}$ \\
\hline Kink $<1$ & 95,189 & $68.5 \%$ & N/A & $37.2 \%$ & N/A & N/A & N/A & N/A \\
\hline $1 \leq$ Kink $<2$ & 18,067 & $13.0 \%$ & $0.8 \%$ & 23.6 & $7.3 \%$ & $1.1 \%$ & $-0.3 \%$ & $20.1 \%$ \\
\hline$\overline{K i n k}=2$ & 8,524 & $6.1 \%$ & $2.1 \%$ & $17.3 \%$ & $21.9 \%$ & $3.1 \%$ & $-1.0 \%$ & $21.2 \%$ \\
\hline Kink $=3$ & 4,307 & $3.1 \%$ & $2.9 \%$ & $14.8 \%$ & $34.7 \%$ & $4.4 \%$ & $-1.5 \%$ & $19.3 \%$ \\
\hline Kink $\geq 4$ & 12,889 & $9.3 \%$ & $2.4 \%$ & $6.7 \%$ & $38.4 \%$ & $4.5 \%$ & $-2.1 \%$ & $13.0 \%$ \\
\hline
\end{tabular}




\section{Table 8}

Characteristics of apparently underlevered firms and comparison sample

Each value shown is computed by first computing that variable's median for each year (from 1980 to 2007), and then averaging the median values. Dichotomous measures (High option deductions, Tech, and Pharma) in the table are the average of the annual means. Positive benefits represent firms that could increase their MVA (i.e., net tax benefits less the increase in the cost of distress from Table 7) if they doubled their debt. NP Kink $\geq 4$ represents firms that have NP kinks of four or greater. NP Kink $<2$ represents firms that are in the top two ROA groups with kinks less than two. Book leverage is total debt over total assets. Debt/Value is the ratio of debt to the market value of assets. ROA is taxable income scaled by average assets. Assets is average assets between $t$ and $t$-1. Firm age is the number of years since the firm's IPO. $Q$ is the ratio of the market value of assets to assets. Asset return volatility is the volatility of the unlevered equity returns computed following Campbell, Hilscher, and Szilagyi (2008). Earnings volatility is the volatility of the ratio of EBIT to average assets. Cash holdings is the ratio of cash and cash equivalents to Assets. Dividends is dividends scaled by average assets. Diff [Accrual tax rate-Cash tax rate] is the difference between the accrual effective tax rate (computed as the ratio of current tax expense over taxable income, scaled by the top statutory tax rate) and the cash effective tax rate (computed as the ratio of cash paid for income taxes over taxable income, scaled by the top statutory tax rate). Foreign asset is the ratio of foreign assets (estimated as in Oler et al. 2007) to assets. High stock option deductions is one if the firm's estimated option value as a percentage of average assets is in the top quintile of all firms. Tech is one if the firm's Standard Industry Classification (SIC) code is 3678, 7372, 7370, 3674, 3577, 3571, or 3572; zero otherwise. Pharma is one if the firm's SIC is 2835, 2834, or 2836; zero otherwise. Reported significance levels are based on Fama-MacBeth standard errors. *** Signify statistically different from the Comparison sample at the $5 \%$ and $1 \%$ levels, respectively. The number of observations for Asset return volatility and Earnings volatility is lower than shown due to missing data.

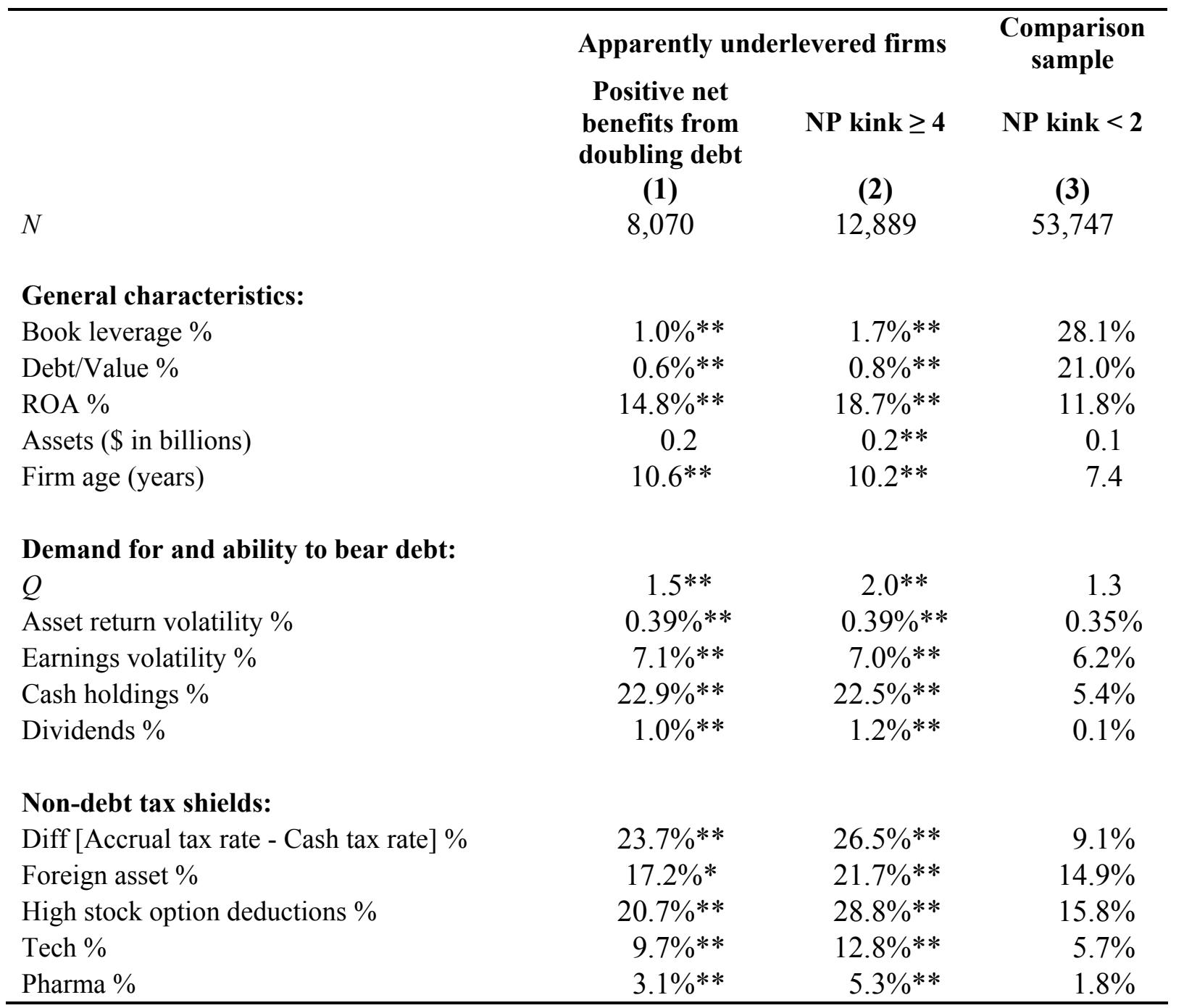


Panel A: Full sample: Firm-years from 1980 to 2002
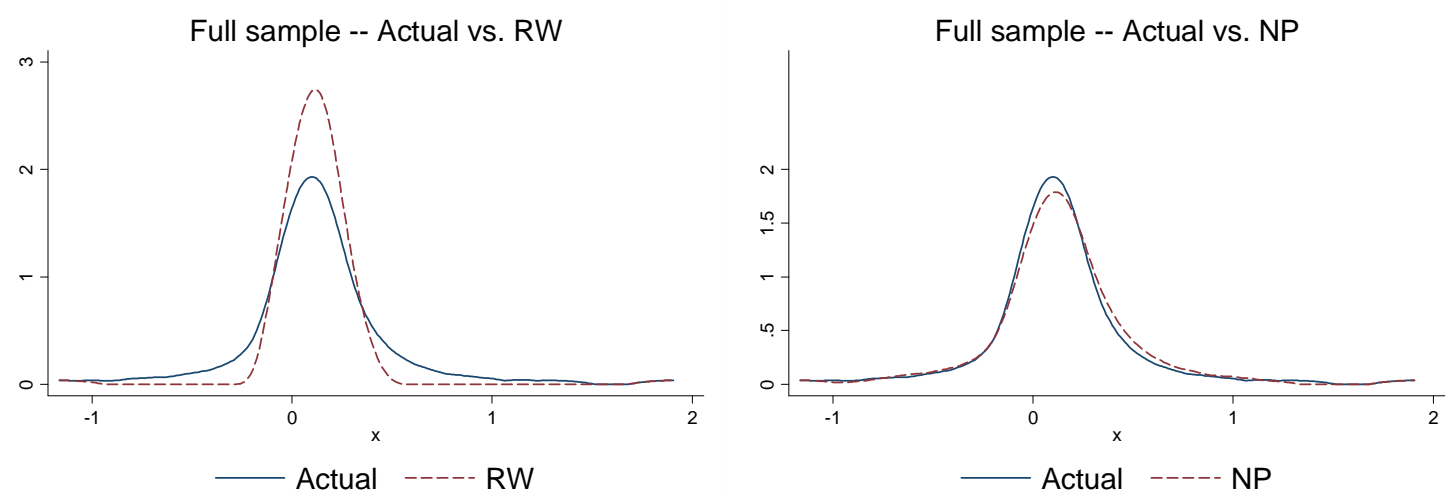

Panel B: Low-income sample: Firm-years in lower half of negative ROA subsample from 1980 to 2002
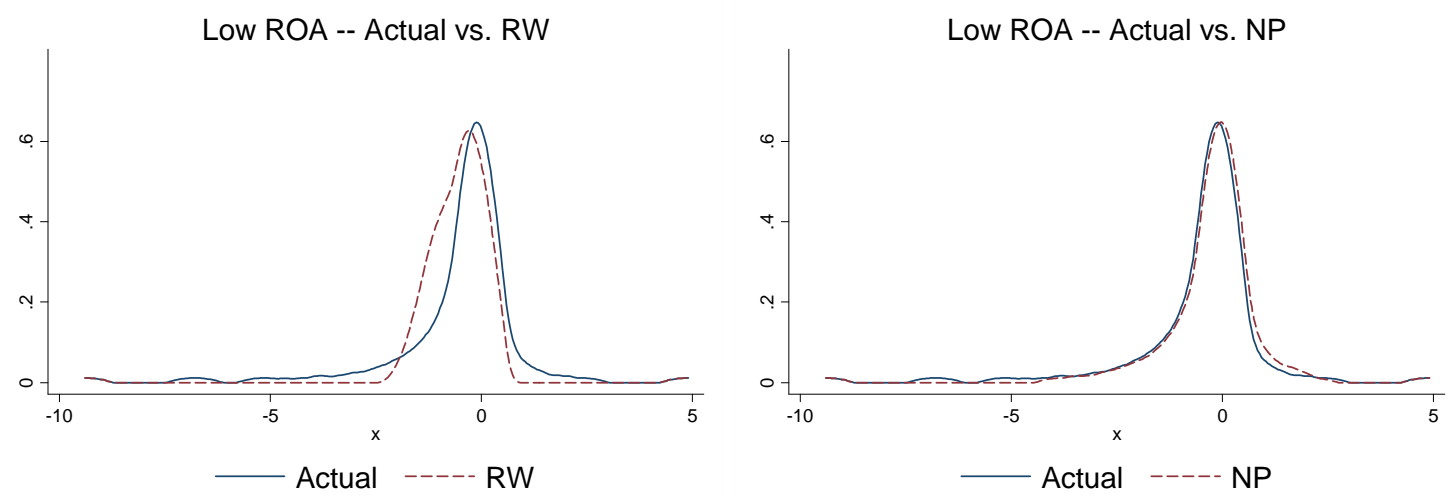

Panel C: High-income sample: Firm-years in upper quartile of positive ROA subsample from 1980 to 2002
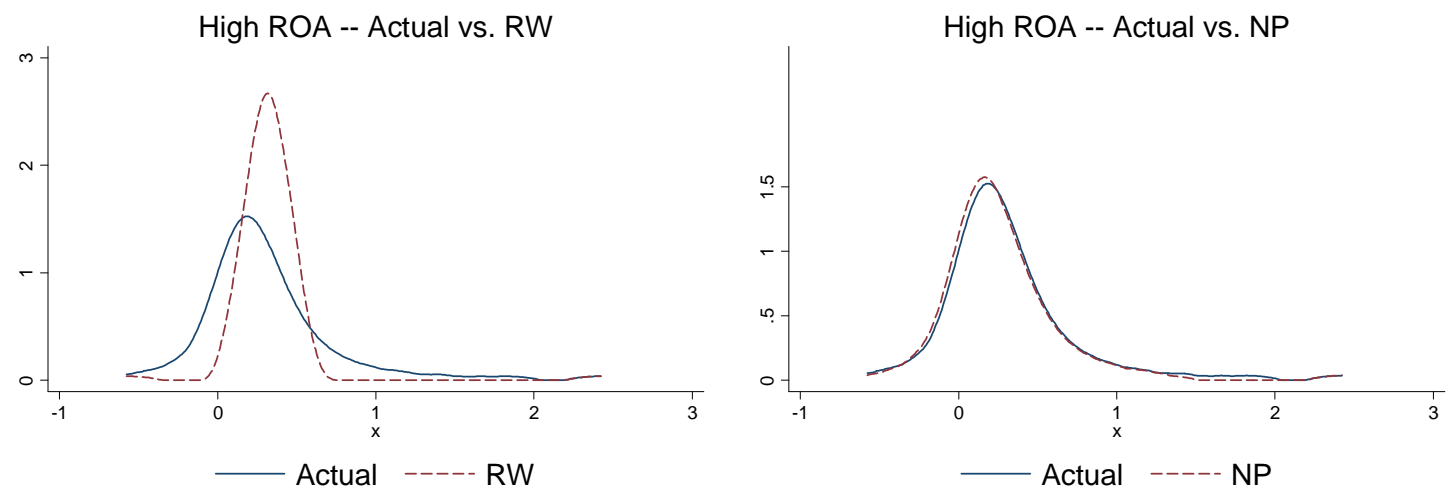

Fig. 1. Graphs of the empirical distribution of five-year-ahead taxable income vs. RW and NP simulated income. Each graph plots the empirical distribution of five-year ahead taxable income (solid line) relative to what the RW model predicts (dashed line; left-hand graph) and to what the NP model predicts (dashed line; right-hand graph). Graphs are generated using a kernel density smoother of income pooled across time. Income is trimmed at the $2 \%$ and $98 \%$ points. 
Rank based on $t-2$

1. Establish bins
$\mathrm{TIBIT}_{t-2} / \mathrm{Ave}\left(\mathrm{TA}_{t-2}\right)=\mathrm{ROA}_{t-2}$

$\operatorname{Ave}\left(\mathrm{TA}_{t-2}\right)=\left(\mathrm{TA}_{t-3}+\mathrm{TA}_{t-2}\right) / 2$

$\operatorname{TIBIT}_{t} / \operatorname{Ave}\left(\mathrm{TA}_{t}\right)=\mathrm{ROA}_{t}$ Ave $\left(\mathrm{TA}_{t}\right)$

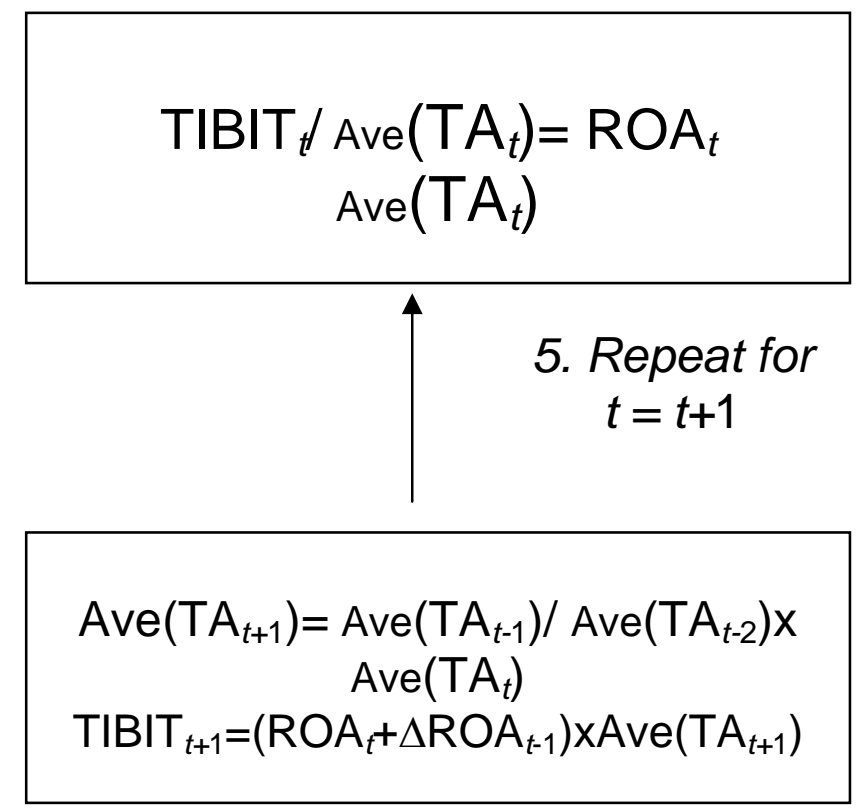

$$
t=t+1
$$

$\operatorname{Ave}\left(\mathrm{TA}_{t+1}\right)=\operatorname{Ave}\left(\mathrm{TA}_{t-1}\right) / \operatorname{Ave}\left(\mathrm{TA}_{t-2}\right) \mathrm{x}$ Ave $\left(\mathrm{TA}_{t}\right)$

TIBIT $_{t+1}=\left(\operatorname{ROA}_{t}+\Delta \mathrm{ROA}_{t-1}\right) \times \operatorname{Ave}\left(\mathrm{TA}_{t+1}\right)$
Place $t-1$ info in bin

$\mathrm{ROA}_{t-1}-\mathrm{ROA}_{t-2}=\Delta \mathrm{ROA}_{t-1}$ $\operatorname{Ave}\left(\mathrm{TA}_{t-1}\right) / \operatorname{Ave}\left(\mathrm{TA}_{t-2}\right)$
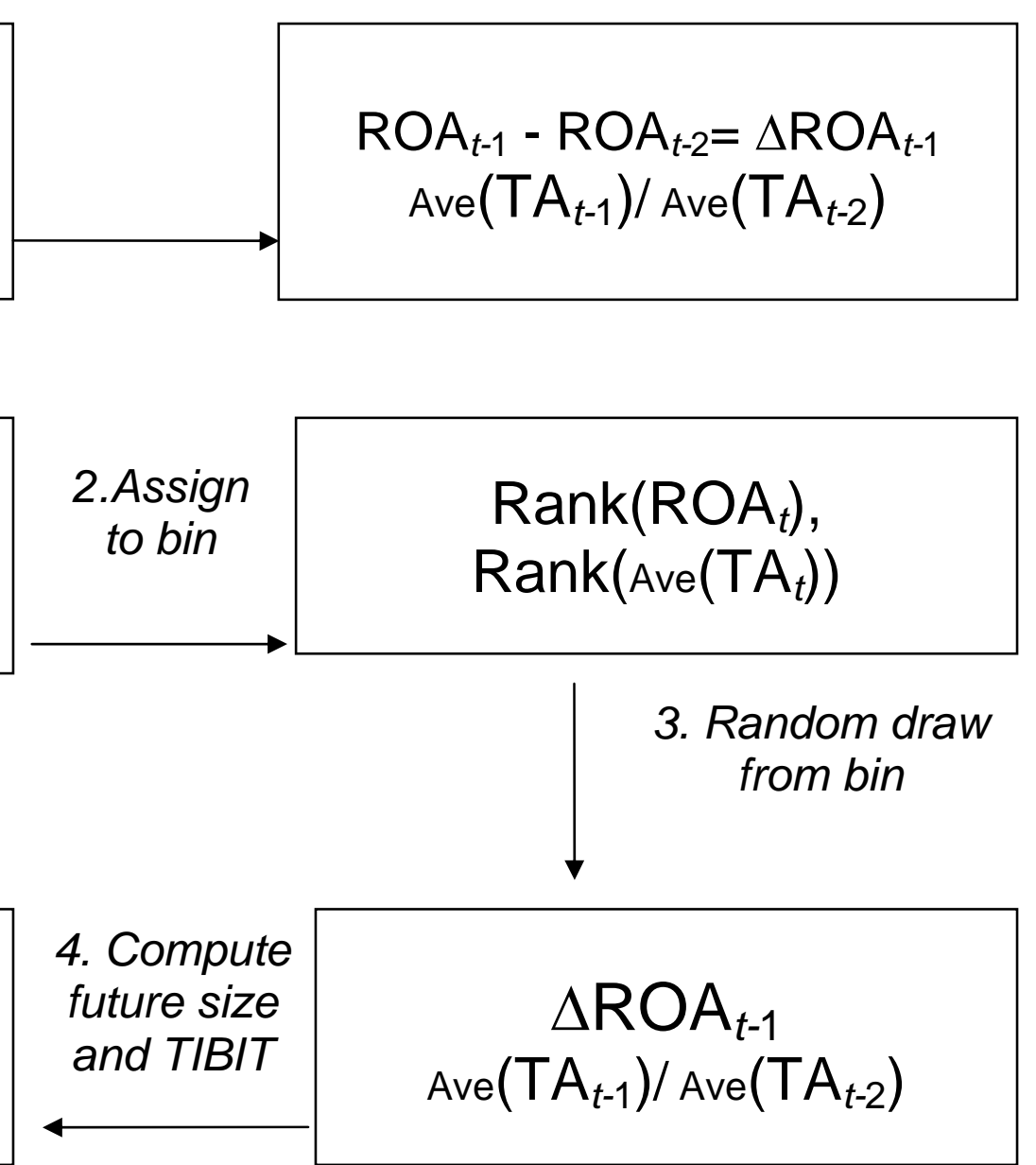

Fig. 2. Illustration of the NP income simulation procedure. TIBIT is taxable income before transitory items. TA is total assets. 